\title{
Seeking Horses: Allies, Clients and Exchanges in the Zhou Period (1045-221 BC)
}

\author{
Jessica Rawson ${ }^{1}$ (D) $\cdot$ Limin Huan $^{1}$ (D) William Timothy Treal Taylor ${ }^{2}$
}

Accepted: 11 November 2021 / Published online: 24 December 2021

(c) The Author(s) 2021

\begin{abstract}
Horses and chariots - and the associated technology and expertise-derived from the steppe contributed to the success of the Zhou conquest of the Shang in c. 1045 $\mathrm{BC}$ and remained important throughout Zhou rule in ancient China. On the basis of material cultural patterns, including the style and material used in bridle cheekpieces found in tombs of the late second and early first millennium $\mathrm{BC}$, this paper points to a northern origin for Zhou horses. Important intermediaries, providing these horses, were the clans whose cemeteries have been identified on the northern edges of the Central Plains. The necessity for repeated exchanges bringing south horses from the north was a consequence of key environmental differences between the steppe and the Central Plains, including climate, geomorphology, essential soil nutrients, and land use. These created significant difficulties in sustainably breeding and pasturing horses of quality. As a result, the people of the Central Plains were bound, over millennia, to seek horses from the northwest, along a cultural corridor that also moved northern materials and technologies, such as gold-, iron- and some bronze-working, into the Central Plains from the steppes.
\end{abstract}

Keywords Zhou $\cdot$ Horses $\cdot$ Non-Ji clans $\cdot$ Cheek-pieces $\cdot$ Minerals $\cdot$ Tomb structures

摘要

在公元前 1045 年前后周伐商的战争中, 源于欧亚草原的马匹和马车技术起到了 重要的作用. 而这些技术的重要性也体现在其后的整个周时期. 从物质文化的 角度，通过检视商周墓葬中出土的公元前二千纪晚期至一千纪早期的马镳，我

Jessica Rawson

jessica.rawson@merton.ox.ac.uk

Limin Huan

limin.huan@arch.ox.ac.uk

William Timothy Treal Taylor

william.taylor@colorado.edu

1 School of Archaeology, University of Oxford, Oxford, UK

2 Museum of Natural History, University of Colorado-Boulder, Boulder, CO 80309, USA 
们认为周人的马匹资源和技术主要来自北方. 而在马匹南下过程中起到重要作 用的是一些生活在中原周边的人群. 由于气候、地貌, 土壤矿物成分以及土地 使用情况的诸多问题，中原大部分地区并不适合繁育马匹. 这使得中原政权无 法完成马匹的自给自足. 因此，中原人在漫长的世纪中持续地寻求从西北引入 马匹资源. 经由这种文化联系, 北方的其他物质文化和技术, 诸如金器, 铁, 青铜 锻造等也逐渐从草原进入了中原地区.

\section{Introduction}

The Zhou conquest of the Shang in 1045 BC is widely recognised as a major turning point in Chinese history (Shaughnessy, 1999). Over the many centuries of Zhou prominence, the strength of their claims to authority underpinned state-building efforts down to China's unification under the First Emperor of Qin in 221 BC. These claims were based ostensibly on the Mandate of Heaven and on the virtue of the first rulers, King Wu, and his father, King Wen, but underlying them was an astute political programme. Over the first one hundred and fifty years of their rule, the Zhou sent members of the royal Ji clan to found states (hereafter referred to as polities) across the Central Plains. At the same time, they also recruited clans with leaders who were not related to the Zhou to establish polities along the northern borders of the precious agricultural land in the Wei Valley and the Central Plains to the east.

During the late Shang period, the Zhou had themselves moved south. And, although we do not know their precise origin, early poems, attributed to the Zhou, indicate that they had moved from less fertile regions to the north, almost certainly from part of the Loess Plateau, north of the Wei River, into the agricultural land (Waley, 1954, pp. 241-243; Shaughnessy, 1999, p. 303). The polities along the northern edges of the agricultural land were important to protect the farmland and settlements, which the Zhou had captured, from people moving south. Far to the north were the horse herders in what is today Mongolia and Inner Mongolia. This was the potential danger. Horses and chariots had already been brought south over several hundred kilometres during the intermittent battles of the late Shang period (1250-1045 BC) (Rawson et al., 2020). Neither the Shang nor the Zhou were in direct contact with these horse owners on the Mongolian Plateau. Instead they were faced with the peoples who were, and who occupied the vast area of diverse landforms and environments, from west of Baoji in the Hexi Corridor to the Yan Mountains, north of Beijing, and beyond into present-day Liaoning province, over an area of more than two thousand kilometres from west to east. This immense region, often hundreds of kilometres north to south, was neither part of the steppe, joining the whole of Inner Asia, nor of the agricultural lands given the general name the Central Plains. Typical monuments and burials of the several identified steppe cultures on the Mongolia Plateau and in South Siberia are not found there, nor are the elite settlements of the Shang and the Zhou. Instead, the great diversity of land and climate supported many different groups of people, who tended to move south towards agricultural areas in the valleys, with better conditions for millet growing. If we look in more detail, in the west we find mountains and deserts, with oases threaded along the Hexi Corridor, leading east to the Wei valley and Baoji; in the centre is 
the Yellow River, running first to the Great Bend and then south, as it embraces the Loess Plateau and the deserts and rolling hills of the Ordos region. From here the land rises by degrees up to the Taihang Mountains, where the Fen River basins extend agricultural land northwards; in the east, the Central Plains are guarded by the Yan Mountains to their north (with modern Beijing towards the western edge). Further low land, north of the Yan Mountains, extends east along the Xar Moron and Luan Rivers.

This bridging area, whose occupants played significant roles throughout the history of early China, has been given various names and has been variously defined. An early designation was as the Northern Zone, with an emphasis on weapons and tools that could be compared with chance finds in Mongolia (Lin, 1986). Some authors regard the area as the frontier of Inner Asia, based on metallurgical culture patterns (Linduff et al., 2017). As the whole of the Arc (defined below) falls within modern China's political boundaries, other scholars incorporate large parts of the area into the late Shang (c.1250-1045 BC) and Western Zhou (c. 1045-771 BC) spheres, without detailed environmental or political distinctions ( $\mathrm{Li}, 2006$; Sun, 2021; Yang et al., 2020). The comments have concentrated on the hybrid nature of the metalwork discovered in the Arc. Multiple combinations and variations of materials taken from north and south, especially tomb structures, ceramic types and horse tack, are typical of the whole Arc. In the 1980s, Tong Enzheng, working on the western extension of highland, southwest of the Hexi Corridor, named the whole area (in Chinese) banyuexing didai, which can be translated as 'the crescent-shaped region' (Tong, 1987). Tong recognised and described the distinctive diverse environments and climates and the many different responses to it of a wide variety of cultural groups. His regional definition is now widely accepted by Chinese scholars and here we adopt the concept, referring to the entire bridging region as 'the Arc'. To the north and west is the Mongolian Plateau, which is often described as part of 'Inner Asia' and also often referred to as 'the steppe'.

Not just in the Zhou period, but throughout China's history, the peoples of the Arc have played important roles in the geo-politics of the settled states and dynasties. Through them, the horses of the pastoralists of the Mongolian plateau (which extends northwards into South Siberia to the Altai and the Sayan) and later their armies have, time and again, impacted the lives of the agriculturalist on the Central Plains. Diachronic climatic factors, especially the changing boundary of the Pacific Monsoon, influence this bridging area, and were key in determining how far north towards the Gobi region millet-based agriculture was possible before desert-like conditions started to prevail. In the period 2500-1500 BC, much of the region supported sedentary farming communities (Zhang et al., 2019), but from 1500 BC and sometimes earlier in some parts, a decline in rainfall caused people to leave their pastures or their settlements and move south. At times this tendency was encouraged by periods of greater moisture that allowed crossings over the Gobi (these were recurring events across the region over centuries: Huang et al., 2003).

Here we pay particular attention to three sub-regions of the Arc along (and within) the northern edge of the agricultural lands of the Central Plains, all of which have particularly well-documented cemeteries and can thus serve as representative case studies. These are (i) the sub-region around, and to the north and west of, 


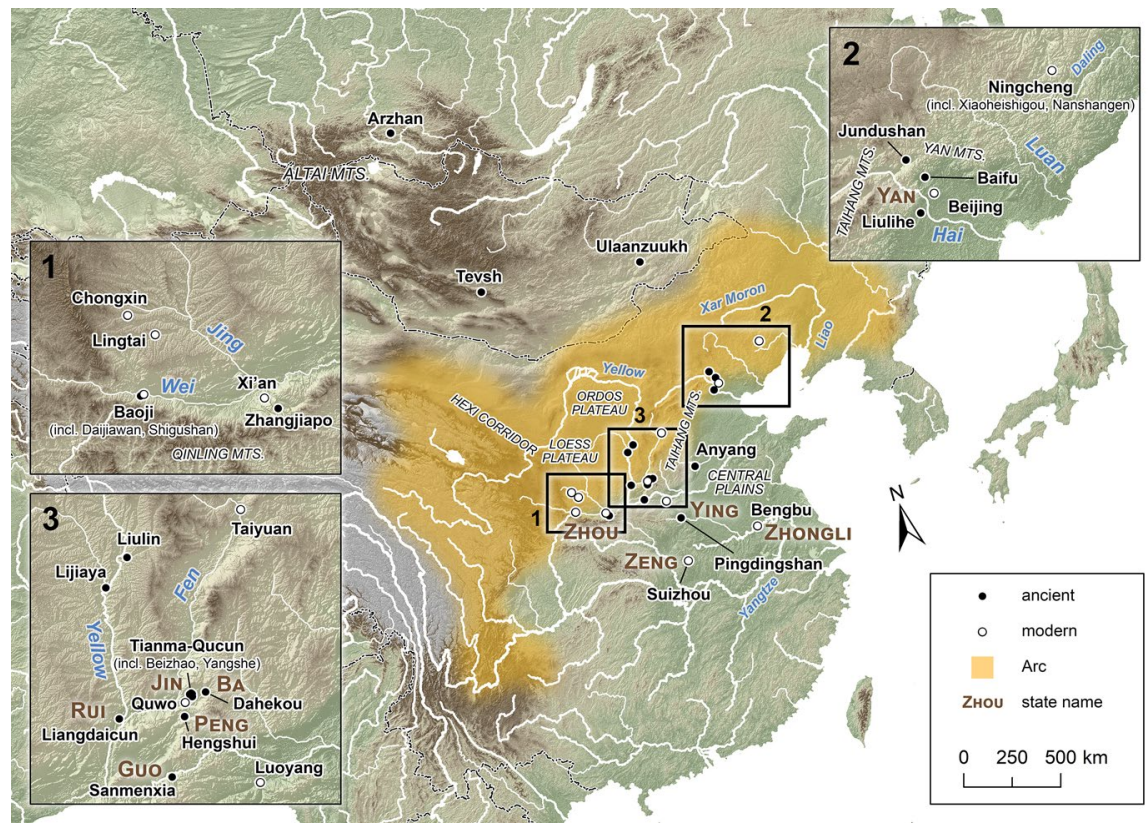

Fig. 1 Map with the Arc, the three sections, and major sites mentioned in the text (map drawn by Limin Huan)

present-day Baoji in the western Wei Valley, $150 \mathrm{~km}$ west of Xi' an, with important south-flowing rivers, the Qian and the Jing; (ii) the sub-region around, and to the north and east of, Beijing along the Xar Moron and Liao Rivers and (iii) the subregion in the Fen River valley, south of the provincial capital of Shanxi at Taiyuan, and including Anyang to the east (Fig. 1). On the southern edges of these three subregions, not only did the Zhou establish polities with leaders from the royal Zhou clan, but at the same time they recognised polities with leaders from completely different clans (we shall term these 'non-Ji clans'). The same practice of recruiting people of non-Ji clans was also followed across large parts of the Central Plains and was fundamental to achieving Zhou success (Khayutina, 2017a; Li, 2006). Yet, despite their claims to rule the whole broad agricultural territory of the Central Plains and more, Zhou control did not extend into the Arc and local areas of farmland were in fact controlled from widely-scattered centres, where local elite lineages dominated only their immediate surroundings.

The three discrete sub-regions we have chosen for study were of particular significance in the Western Zhou period, as all three provided buffers against intrusive movement southwards into agricultural areas during the centuries when the administrative centre was near present-day Xi'an (1045-771 BC). During the eighth century BC new invaders, named in vessel inscriptions and transmitted texts as either the Quanrong or the Xianyun, drove the Zhou from their centres near Xi' an to the secondary capital at Luoyang, demonstrating the need for some kind of enhanced defence. 


\section{Historical Overview}

By the time that the Zhou had conquered the Shang in c. 1045 BC, they had seemingly mastered the scribal use of Chinese characters and followed rituals of offerings to the ancestors made in bronze vessels, which would appear to have been part of their means of extending control over former Shang lands. Zhou interaction with their close northern neighbours-integrating them as polities within their ritual and military systems - was much more extensive than that of the late Shang. Some Shang outposts in the Loess Plateau have been found, and Shang bronze vessels have been found widely distributed in the Arc, having possibly been exchanged for horses (Cao, 2014). But there was, on present evidence, no systematic attempt under the late Shang to create a chain of allies on the borders of the Central Plains (Rawson et al., 2020), as the Zhou were to do.

From the ninth century BC, a period of wars began with the Quanrong in the western areas of the Arc, bringing to an end Zhou control of the Wei valley in the eighth century BC ( $\mathrm{Li}, 2006)$. Separately, invasions by peoples from South Siberia and the Mongolian Plateau limited Zhou control of the north-eastern regions of the Arc around present-day Beijing. Thus the Western Zhou centuries, bookended by these two very different interactions with the peoples of the Arc, must be considered as very important phases of expansion, leading to the extension of control over the western and northern parts of the Central Plains.

The centuries of the Western Zhou were also an unusual time when non-Ji polities along the northern boundary of the Central Plains made a distinctive contribution to the success of the Zhou by providing horses and chariots for Zhou armies. Through the non-Ji association with the Zhou, as well as with polities on agricultural land, these non-Ji clans had interactions southwards with the Zhou and northwards with Inner Asia. They acquired sufficient wealth in some instances to create large cemeteries and substantial tombs for their leaders. Neither the tomb structures nor the vessel sets that they had acquired conform with Zhou practices. These many unusual weapons, shields and horse equipment show that several of these non-Ji clans shared, across a wide area, similar local weapons, which differed from those of the main Zhou leaders. From their weapons, chariot tools and (most especially) the horse equipment, we argue that the non-Ji clans were valued as fighters and for their skill in management of, or even for their supply of, horses from the north. Considering larger chronological patterning across later centuries, we infer that this contact continued as the searches for horses from the northwest were renewed over the centuries.

\section{Horses in East Asia}

The introduction of horses into the Central Plains, and relationships to the Mongolian Plateau, were essential to the early history of warfare in China. The Zhou and their allies were, themselves, skilled chariot drivers and drove, on occasion, 
four-horse chariots, requiring yet more horses and horse managers than the twohorse version.

Until fairly recently, many scholars presumed that the first East Asian horses were descendants of those discovered at Botai in Kazakhstan (Outram et al., 2009). However, renewed archaeogenetic study shows that the Botai horses were a different taxon, Equus przewalskii (Gaunitz et al., 2018), while dental features, once taken as evidence for horse transport on these animals, appear to have natural, non-anthropogenic causes (Taylor \& Barrón-Ortiz, 2021). Instead, beginning in the early second millennium BC, the earliest domestic horses appear to spread eastwards from the Black Sea steppes and the trans-Ural region (Chechushkov \& Epimakhov, 2018), where they appear to have been closely paired with chariots.

Available evidence suggests that the rise of the Zhou followed the proliferation of horse culture in the Mongolian steppes to the north. DNA sequencing of archaeological specimens indicates that the first horses to reach Mongolia were Equus caballus, the ancestor of the modern horse (Fages et al., 2019; Gaunitz et al., 2018; Librado \& Orlando, 2021; Librado et al., 2021). Excavations at large stone burials/monuments, named khirigsuurs, reveal extensive use of horses in ritual deposits around these large stone-fenced structures in the landscape of the Plateau and surrounding regions by c. 1400 BC (Allard et al., 2007; Taylor et al., 2017, 2019). Recent work by Yuri Esin, collaborating with colleagues in Mongolia, and examining petroglyphs depicting chariots in the Khoid Tamir valley, has proposed a date for the widespread use of chariots and horses in Mongolia in the centuries prior to $1200 \mathrm{BC}$ (Esin et al., 2021). Tall stelae, known as deer stones (Fig. 2), produced by the same culture also show

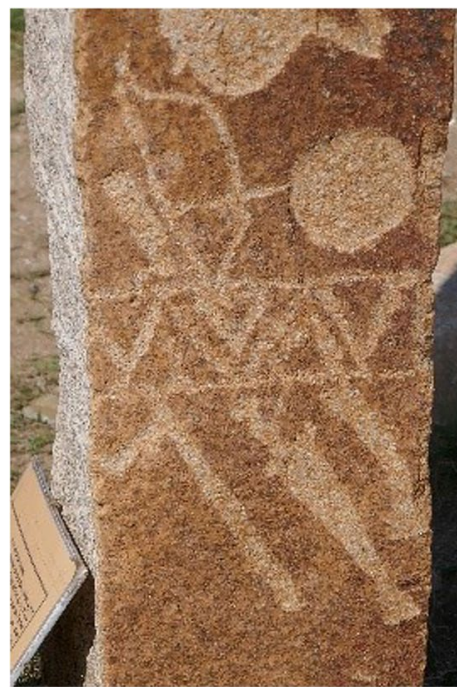

a

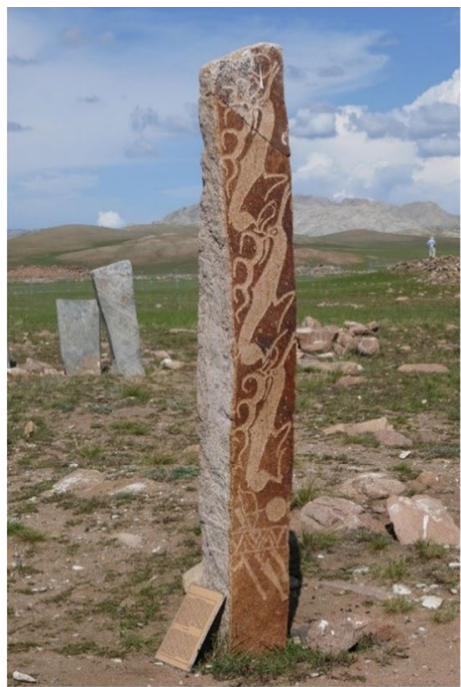

b

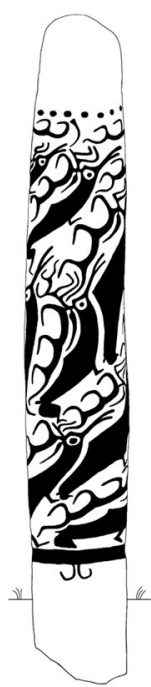

C

Fig. 2 Deer stones in Mongolia. a, b photos of a deer stone, Khovosgol Province, and its detail, showing steppe-type weapons attached to a belt (photos by Jessica Rawson); c drawing of a deer stone showing a rein holder (with two hooks) attached to a belt, Sharvartiin, Arkhangai aimak, Central Mongolia (after Volkov, 2002, pl. 5) 
engraved weapons (daggers, curved knives and shafted axes) and shields, along with curved hooks thought to have functioned as rein-holders for horse control, hanging from a belt around the stones (Fitzhugh, 2009, p. 185; Volkov, 2002). Horse silhouettes and, occasionally, chariot images are engraved on these stones, pointing to an important role for this culture in the dispersal of horses and chariots into East Asia.

Osteological and pathological features suggest that horses of the Deer StoneKhirigsuur (DSK) complex were regularly used for transport (Taylor \& Tuvshinjargal, 2018; Taylor et al., 2015). While distinguishing between riding and chariots can be challenging, the imagery, archaeological context, and the unique osteological features found on these early horses suggest that chariots, rather than mounted riding, were the most important form of transport (Taylor et al., 2021). On the basis of indirect evidence such as human joint pathologies (Grupe et al., 2019; Wagner et al., 2011), some scholars have convincingly argued that horses from Mongolia and northwest China must have been ridden when managing horse herds as early as the second millennium BC (Grupe et al., 2019). However, to date, the earliest indisputable archaeozoological evidence for mounted horseback riding in East Asia, in the form of riding tack and equine pathologies, dates to the mid first millennium BC (Drews, 2004; Li et al., 2020).

The archaeological record of early horse use on the Mongolian Plateau is a key to the introduction of horse-drawn chariots to the late Shang at Anyang (Rawson et al., 2020). So-called 'prone burials' south-east of the main Plateau include horse remains dated to the late second millennium BC (Taylor et al., 2017). Artefacts from these burials provide important evidence on the origin of the Shang chariot and its horses (Rawson et al., 2020). In addition to grave goods offering evidence of cultural connections, this unique burial style links people from the Plateau with the first Chinese chariots: in a chariot pit at the cemetery of Dasikongcun, north of the Huan River at Anyang, the chariot driver was buried, like many others at the Shang capital, in a prone body position (Fig. 3). It may be that the Shang, as they began to acquire the chariot and its horses from the north, also engaged people from the same areas to manage horses, including the chariot drivers who, at death, were buried in a downward-facing position.

That the Zhou and their allies must have continued to source their horses from the north, either from the Mongolian Plateau or from further north and west, becomes clear if we look at the types of cheek-pieces used. During the late Shang and the first decades of Zhou military action, the principal horse harness made use of pairs of rectangular bronze cheek-pieces, with a single hole, two tubes, and a slit for a nose band. The use of bits is debated (Figs. 3 and 4) (Chechushkov et al., 2018; Littauer, 1969; Usachuk, 2010; Taylor et al., 2015, p. 287; Stepanova \& Chugunov, 2019). The cheek-pieces were often, but not invariably, employed with a spiked liner, reproducing the impact of the oval or round bone cheek-pieces with rounded spikes found at Sintashta in the eastern Urals and other sites in the western steppe in the early second millennium. A relatively sudden change took place in the early tenth century $\mathrm{BC}$, as the Zhou adopted rod-shaped versions in antler and bone, which had for long been common over a wide area including Ukraine and several other parts of Europe, Iran and the western and eastern steppe (Boroffka, 1998; Britnell, 1976; Podobed et al., 2014). This change suggests the arrival of new groups of people settling 


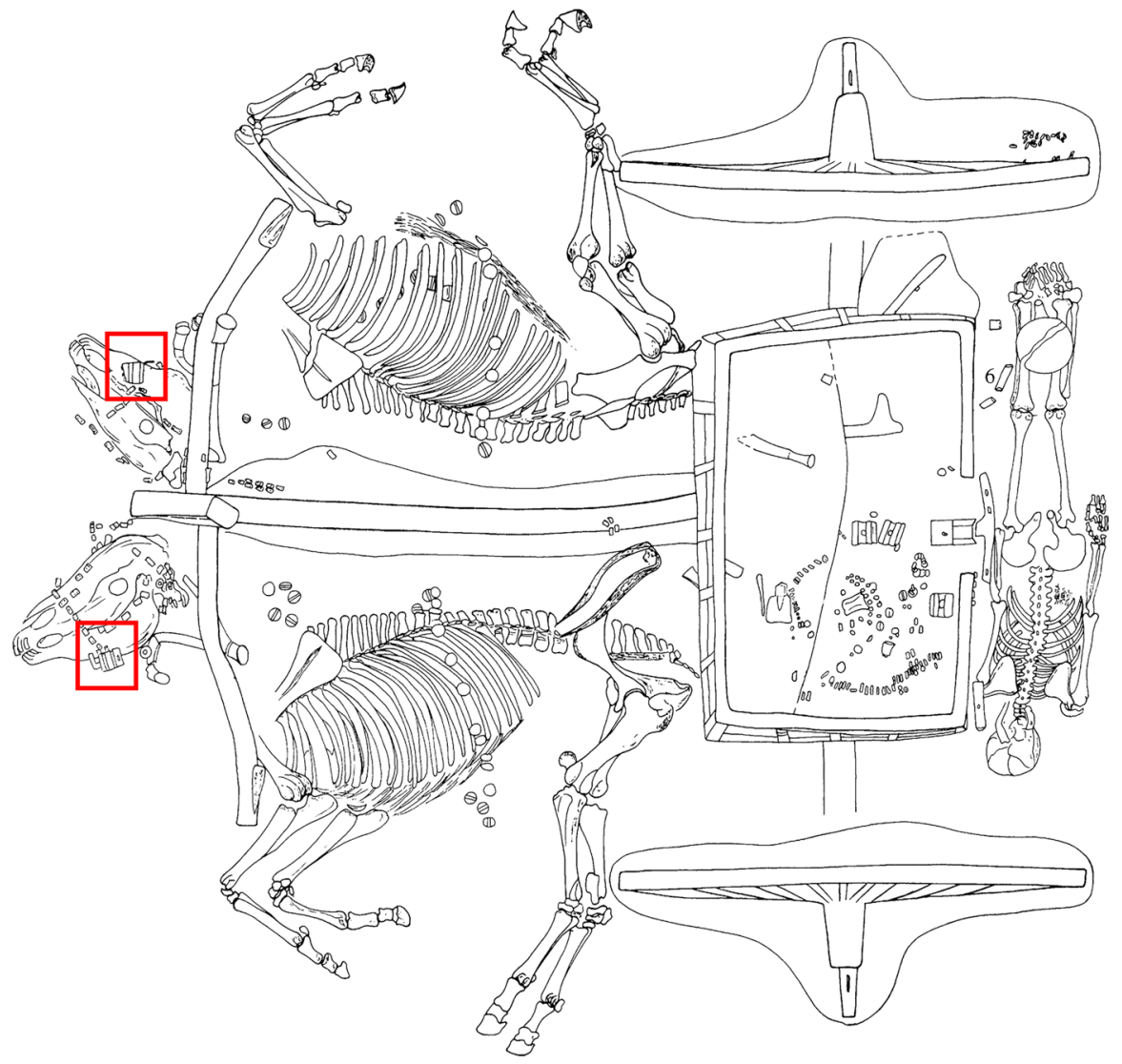

Fig. 3 Plan of the chariot burial M226 at Dasikongcun, Anyang, c. 1200 BC, with the chariot driver buried prone (after Zhongguo, 2014, vol. 1, Fig. 416)

among the Ji and non-Ji clans and introducing this new form of harness. The Zhou were already perfectly equipped to cast bronze cheek-pieces; antler and bone were, after all, less durable than bronze, with which material they could be replaced. But new antler cheek- pieces continued to appear in the Central Plains, suggesting that new people and new horses joined the non-Ji clans, and even the Ji-clans, over several centuries that saw a constant demand for horses from the north (the significant environmental barriers to breeding strong horses on the Central Plains remained the limiting factor in any domestic supply).

Other tools, found with charioteers buried at Anyang, and including rein hooks, curved knives, chisels and socketed axes, provide additional evidence of the first northern contacts. Significant numbers have been found south of the Mongolian Plateau, along the northern section of the upper Yellow River (Cao, 2014; Rawson et al., 2020; Yang \& Liu, 1998). The curved knives vary: some carry animal heads, such as those depicted on deer stones; others resemble examples found in archaeological contexts in the Arc; yet others appear to have been cast at Anyang. Socketed 

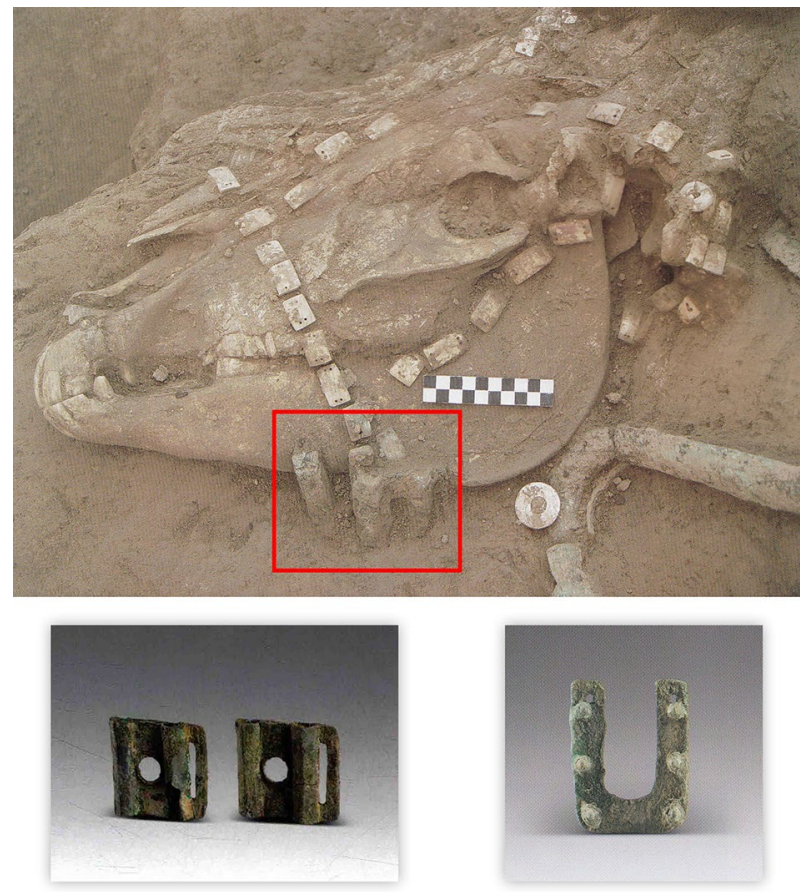

Fig. 4 Top Remains of the horse head in M226. The cheek-piece and spiked fitting are visible in the picture, attached at the bottom of the noseband; bottom bronze cheek-pieces with an example of a spiked liner (after Zhongguo, 2014, vol. 2, pls. 129:4; 130:3)

axes, spade-like celts and chisels, required to repair the chariots, also match those found in mountainous regions of Inner Asia (Kuzmina, 2008, figs. 52-54).

Using three case studies, we show how people living alongside the Zhou polities of the Ji clan were major intermediaries in the transfer of horse management, and almost certainly also horses, to Zhou polities and settlements.

\section{Case Studies in Three Regions of the Northern Edge of the Central Plains}

Here we examine tombs from the three major sub-regions where the Arc meets the Central Plains and where potentially fine agricultural land adjoins the Loess Plateau and the mountains around Beijing (Fig. 1). Sites outside these defined case-study sub-regions are certainly also important, but we have concentrated on those with the most substantial cemeteries and which have been well documented (Sun, 2021). Following Shang use of horses for chariots, the earliest Zhou period tombs with horse equipment, dating to the eleventh and tenth centuries BC, are found around Baoji in Shaanxi and neighbouring eastern Gansu among polities of non-Ji clans. It is even more remarkable that it is here, in these tombs, that the very largest numbers of the earliest Zhou period ritual vessels have come to light. It is likely that the Zhou had 
long-term contacts with the Baoji district and they may even have entered the Central Plain here, driven (it is sometimes suggested) by climatic changes or (at least) by disastrous winter weather conditions (Huang et al., 2003). In this region four cemeteries were created by people who seem to have been allies of the Zhou. The most recently discovered is at Shigushan (with its associated bronzes at Daijiawan), with the two best known cemeteries of the non-Ji Yu lineage both on the river terraces of the Wei valley south of Baoji; further north and west there are cemeteries at Lingtai, also with claims to be occupied by a non-Ji lineage, and at Chongxin in eastern Gansu. At the same date as these cemeteries were founded, members of the Ji clan may have established the Rui polity to the north of Baoji (Khayutina, 2017a, pp. 308-311; Chen, 2015), and we here also compare tombs attributed to the $\mathrm{Ji}$ at Zhangjiapo, near Xi' an. Next in date, during the late eleventh and early tenth century BC, are tombs of the Yan polity of the Ji clan at Liulihe near Fangshan, southwest of central Beijing. At this locality, a small group or a clan, without a claim to any named polity, was buried at Baifu near the Jundushan Mountains. The most extensive cemeteries are those in the third area, where the Fen River joins the Yellow River as it flows south. At a point where several narrow agricultural basins lie surrounded by higher ground, two very large non-Ji polities appear, the Ba and the Peng, which endured for a period of around two centuries. They were named with Chinese characters, and thus we can presume that they were recognised and accepted by the Zhou. Not far from the Ba polity was the Jin polity of the Ji lineage, founded by a brother of the first Zhou King, Wu. Two Jin cemeteries have been excavated, one consisting of elite tombs at Tianma-Qucun, and the other of the ruling Jin lords, their spouses and chariot burials at Beizhao and Yangshe. Led by members of a further branch of the Ji lineage, the Rui polity, which had probably first been located near Baoji, moved to the area in the ninth century BC, occupying territory on the other side of the Yellow River at Hancheng. The cemetery there, at Liangdaicun, offers abundant information on the interaction of the royal Ji lineage with members of non-Ji polities (Rawson, 2013). Their visible cooperation will be contrasted with the situation that developed after the collapse of Zhou influence in the Wei valley in the eighth century BC. The period down to that point is traditionally known as the Western Zhou; following the movement to the secondary capital of Luoyang, the centuries down to the Qin unification are now called the Eastern Zhou (770-221 BC).

In our discussion of the three areas with cemeteries of the leaders of non-Ji clans, the following features or attributes are taken as defining the occupants as having backgrounds unlike those of the Ji lineage and their followers on the Central Plains. First and foremost are the structures and orientations of their tombs, which differ markedly from those of the Ji and their followers, which were oriented north-south, with the body of the tomb occupant in a supine body position. Moreover, the diversity of these structures indicates that the leaders of these polities did not come from one single region. Nor were they united in their use of weapons; some indeed show links with south-west China. Many of the weapons, such as mace-heads (Li, 2018), different forms of shafted or shaft-hole axes, mattocks, and curved knives have long been identified as typical of peoples in the so-called 'Northern Zone', across the centre of the Arc and on the eastern edges of Inner Asia (Yang et al., 2020), but 
these have rarely ever been examined within their full burial contexts. Shields are surprisingly prominent in some of these tombs. Occurring frequently, but not universally, are forged bronzes, helmets in bronze, bronze bosses (on tunics, leggings, or boots), bone or antler plates to form armour, and elaborate beaded ornaments. None of these are characteristic of the Central Plains and signal their owners' contacts with Inner Asia. However, the size and complex structures of the tombs (adapting features used by the Ji clans) and the multitude of possessions made of bronze suggest that most clans had not recently moved from Inner Asia, but had already been established for long periods in more local parts of the Arc. All these tombs display either early square bronze cheek-pieces (Fig. 4) or horse harness with various different forms of the rod cheek-pieces, most prominently made of antler (which are central to the discussion here). With the exception of two small tombs at Liulihe, all tombs also include ritual vessels, probably cast at the main Zhou administrative or palace centres. These may have been acquired as booty, but were more probably gifts from the Zhou. These vessels are often of very high quality and many carry inscriptions naming former owners. Such vessels indicate that their new owners were recruited as allies or clients of the Zhou and were certainly not enemies; rather they had joined in the campaigns and enterprises of the Zhou. The importance of this political strategy for Zhou success cannot be overestimated.

\section{The Western Wei River Valley and Southern Gansu}

The two major cemeteries on the river terraces of the Wei Valley, south of Baoji, preserve unusual tomb structures. The tombs at Shigushan present niches on the secondary ledge which held large numbers of ritual vessels (Fig. 5) (Liu et al., 2013; Wang et al., 2016). The large southeast-northwest oriented tombs of the leaders of the $\mathrm{Yu}$ at three nearby cemeteries have space for a secondary burial of a female companion within them (Fig. 6) (Lu \& Hu, 1988). Although both kinds of structure have the deep pits, coffins and secondary ledges typical of both Shang and Zhou tombs, neither is typical of the Central Plains. The earliest Yu tomb ( $\mathrm{Lu} \& \mathrm{Hu}, 1988, \mathrm{pp}$. 17-35) and those at Shigushan, with the famous groups found in the early twentieth century nearby at Daijiawan (Chen, 2015), together preserved the largest number of mid- or late-eleventh century BC bronzes known to date. This phenomenon alone is very surprising, suggesting that the people in this region were politically or militarily influential and were rewarded at the time of the conquest and its immediate aftermath. The most elaborate of the bronzes were even cast at the Anyang foundry at Xiaomintun and must have come to the Baoji area either first as gifts to the Zhou, or as post-conquest gifts from the Zhou to their allies (Chen, 2015, pp. 482-485; Yue, 2006; Zhang, 2019). The numbers are far higher than those required for ceremonial banquets, notably those found in Shigushan M4 (Wang et al., 2016). A chronological sequence of ritual bronzes in the tombs of the Yu leaders shows us that their vessels followed almost precisely the changes in shape and design used in other major Zhou polities, confirming that the Yu remained in close contact with the Zhou down to near the end of the tenth century BC ( $\mathrm{Lu} \& \mathrm{Hu}$, 1988). Such sequences, seen also in the Fen Valley, confirm that these non-Ji polities were recognised and 

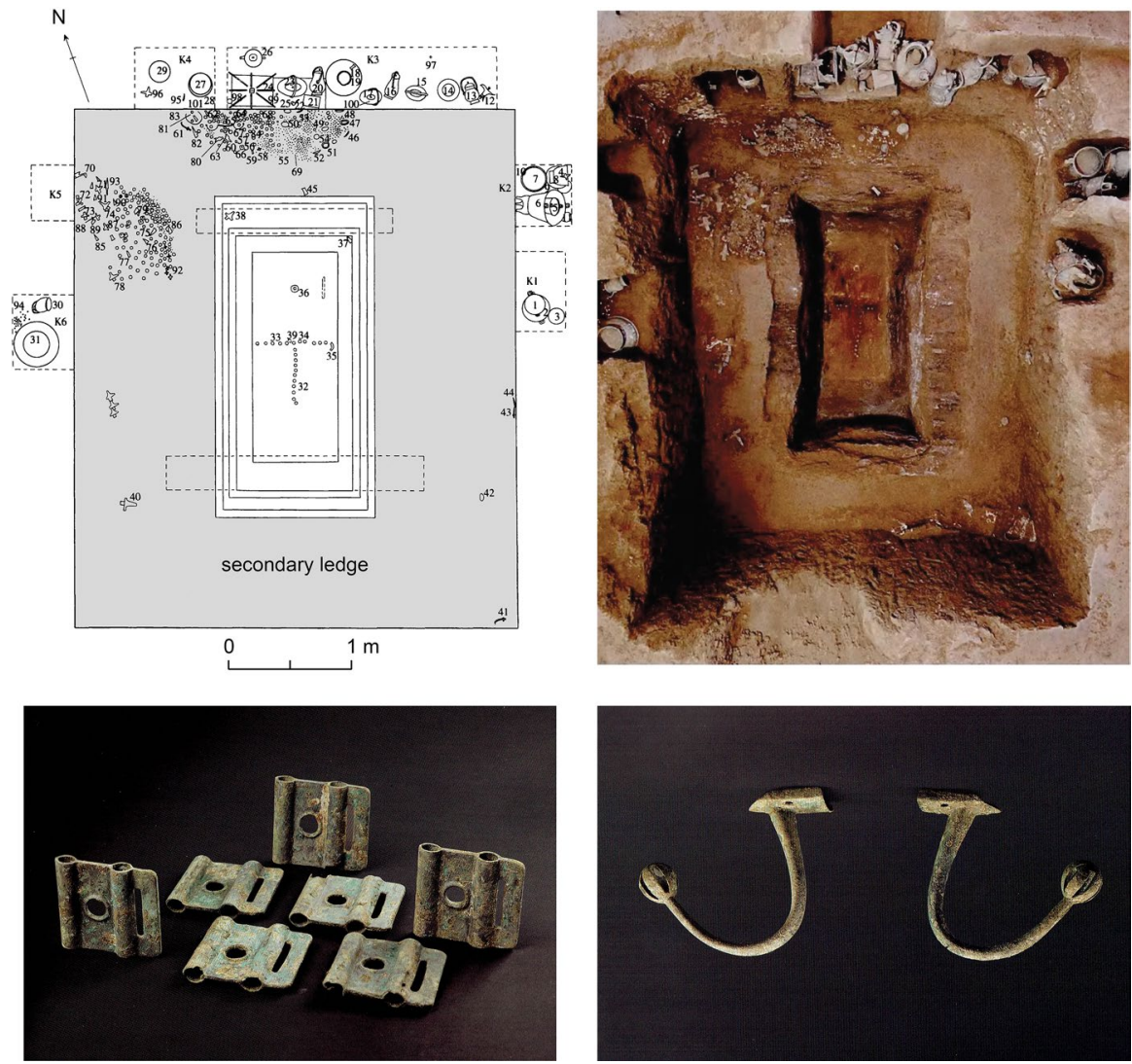

Fig. 5 Top plan of Shigushan tomb M3, Baoji, Shaanxi province, eleventh century BC (after Liu et al., 2013, figs. 3; 4); bottom cheek-pieces for nose bands and hooks with jingles (after Shanghai, 2014, Pls. $6 ; 82$ ). These separate hooks differ from the standard Shang form where the hooks were joined with a curved bar

accepted within the Zhou realm over a long period and must have been courted as valuable allies or clients. Inscriptions on the bronze vessels in different cemeteries indicate that many had been made for earlier owners and were later, after the Zhou conquest, allocated to the leaders in the western Wei valley (Hwang, 2012). Some locally made bronzes in the tomb of the last leader, buried at Rujiazhuang, illustrate a relatively low level of local skill and contrastively serve to confirm that many of the other bronzes must have come from metropolitan workshops (Lu \& Hu, 1988, pp. 366-371). We suggest that all the members of the small polities in the Baoji area were recruited for Zhou military forces in order to help attack the Shang, and were subsequently rewarded with land and bronze vessels as allies and clients.

In this case study, a particularly interesting item from Shigushan is a pair of hooks with jingles at each end (Fig. 5). At Anyang, such rein hooks were standardised in a form in which a curved bronze bar was cast with a hook at each end, and there is so far no evidence of this kind of variation in any Shang or Zhou tombs (Zhongguo, 
Fig. 6 Plan of tomb M13 of Yu state at Zhuyuangou, Baoji, Shaanxi province, end of the eleventh to the tenth century BC (modified from $\mathrm{Lu} \& \mathrm{Hu}, 1988$, fig. 34)

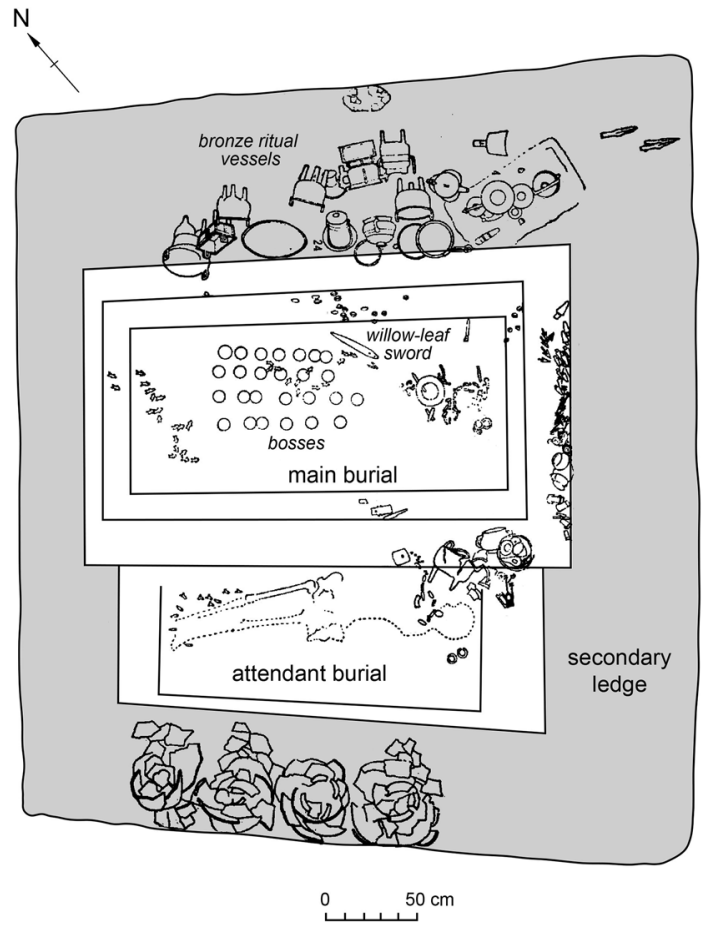

2007, col. pls. 27, 28). However, almost identical items are depicted on deer stones in Mongolia, where charioteers appear to have used a wide range of hook stylesranging from curved bronze bars similar to those at Anyang, to individual hook pairs like those at Shigushan. Deer stone carvings indicate that such hooks would have been attached to a person's belt, and used as rein-holders (Fig. 2c). The Shigushan hooks imply that the deceased had connections with areas to the north, where a greater diversity of rein-holder type was used. The horse cheek-pieces in this tomb are the square type, with a slit for a nose band, and were used either without a bit or with one of an organic material (Fig. 5) (Liu et al., 2013, fig. 72:7). Spikes for an interior lining of a cheek-piece were found among the horse tack at Lingtai, where a horse head was buried in a niche in one of the tombs (Chu, 1977, figs. 2 \& 15:4).

A highly significant form of horse cheek-piece was retrieved from an early tenth century BC Yu polity tomb, M7 (Fig. 7d; Lu \& Hu, 1988, p. 123, fig. 97:2). Its curved top and three holes imitate in bronze a cheek-piece type widely used in antler or bone over an immense area. Antler cheek-pieces were used not only across South Siberia but also on the Mongolian Plateau during the early first millennium BC (Taylor et al., 2016, p. 557, Fig. 2). The central hole of the three in such rodshaped cheek-pieces was aligned at right-angles to the upper and lower ones. The same pattern was reproduced in the bronze copies, indicating that the steppe-Inner Asian version provided the model. These narrow, slightly bowed check-pieces may have been tied to a bronze bit, or attached through the central hole to one of an organic material, or wrapped around an antler tine, with the bridle secured to 


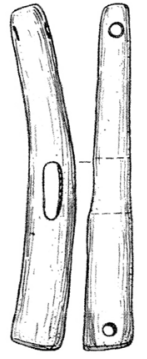

a



b

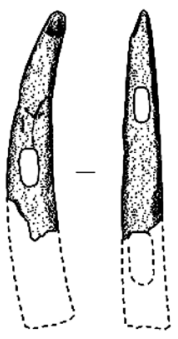

C


d

e
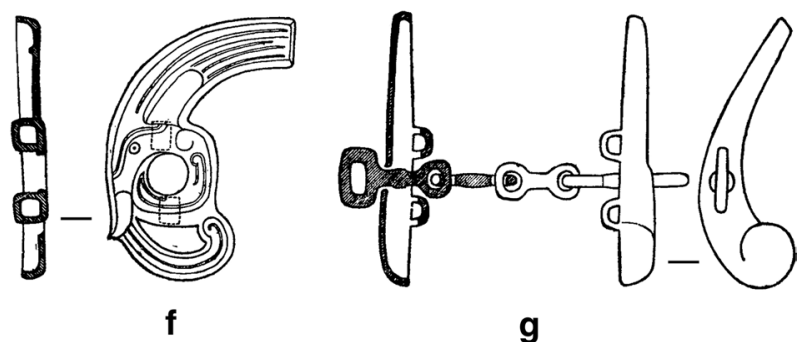

g

Fig. 7 Cheek-pieces of the narrow rod-like form used in the steppe, with versions in bronze from the Yu state, Baoji, Shaanxi province, tenth century BC. a Fortified settlement of Subotovo, Ukraine, eleventh to ninth century BC (after Podobed 2014, fig. 7:4); b Kordlar tepe, Iran, 1250-1050 BC (after Podobed 2014, figs. 1:3; 4); c Sayany-Pogranichnoye-4 (after Amzarakov et al., 2015, fig. 4); d bronze cheek-piece from Yu lineage tomb Rujiazhuang M1 (after Lu \& Hu, 1988, fig. 97:2); e Bronze cheek-piece from the Yu lineage tomb Zhuyuangou M7, tenth century BC (after Takahama, 2020, fig. 7:1); f, g Bronze cheekpiece from the Rujiazhuang M1, late tenth century BC (after Lu \& Hu, 1988, fig. 222: 1, 2)

the cheek-piece through an upper and lower hole. The type demonstrates extraordinarily widespread contacts and influences extending as far west as Ukraine and Europe (Fig. 7a, b), as far east as the Minusinsk Basin (Fig. 7c) and thence into the Arc, where the same form was employed by the non-Ji clan taking the name $\mathrm{Ba}$, as detailed below (Amzarakov et al., 2015; Boroffka, 1998; Britnell, 1976; Podobed et al., 2014; Takahama, 2011).

Few of the weapons from Shigushan have yet been published, but materials from other sites in the region also clearly reflect the broader connections of this artefact 
category. Weapons common in the Arc, but not on the Central Plains, or further west, are generally referred to as belonging to the Northern Zone (Yang et al., 2020). Both the Yu tombs ( $\mathrm{Lu} \& \mathrm{Hu}, 1988$, figs. 59-62) and those at Lingtai (Chu, 1977, figs. 13:3, 4) contained a fine array of unusual axes, one with a head above its shaft in the Yu tomb M13; also present were a mace-a weapon type associated with the Arc (Li, 2018) - and a mattock. A curved axe was also found at Lingtai (Zhang, 2014). The Yu leaders each had a bird-headed staff for banners, and willow-leaf swords, which are the absolute earliest examples of swords or daggers in China. The leaders at Lingtai had curved knives instead, similar to those depicted on deer stones. At Yu we find beaded ornaments of carnelian and faience, similar to those known from South Siberia (Novozhenov, 2012, p. 18, fig. 1); they also contain bosses (Fig. 6), which were probably appliqués that originally attached to tunics, leggings or boots; some may have originally been components belonging to organic shields which do not survive archaeologically either (the probable presence of which is indicated by the survival of some large bronze rings). Shields were clearly valued by the people buried at Chongxin, where substantial bosses of forged bronze have been recorded (Gansusheng, 2009, pl. 5:1). Because forging was not used on the Central Plains at this date, these are also signs of contact with people in Inner Asia or even further west (Chen et al., 2015). Perhaps the most remarkable example is a greave of forged bronze in tomb M1 at Shigushan - a form of armour also completely foreign to the Central Plains (Liu et al., 2013, p. 13, fig. 15). Furthermore, the small rectangular bone plates that were used by the Chongxin peoples in constructing their body armour (Gansusheng, 2009, pl. 49) are similar to those found at Rostovka in Siberia (Matyushchenko \& Sinitsyna, 1988). While the non-Ji clans flourished in the western Wei valley until towards the end of the tenth century BC, thereafter they appear to have abandoned use of bronze ritual vessels or may have moved elsewhere. By this time, another people, described by the Zhou as the Rong, had started to advance southward (Li, 2006, pp. 180-185).

To illustrate the impact of the new forms of antler cheek-piece introduced at a Ji-clan cemetery at Xi' an, we will look briefly at material excavated at Zhangjiapo (Grieß et al., 2010; Zhongguo, 1999). Three major tombs of the Jing lineage (a Ji clan) were installed in a large cemetery with numerous smaller tombs. Bridle cheek-pieces and bits in these tombs include many examples of both antler and bronze, dating to the tenth, ninth and even eighth centuries BC. Among the oldest at Zhangjiapo is a pair of circular cheek-pieces, representative of a style that, in the early tenth century BC, replaced its square precursors. The use of complex bronze bits (Fig. 8a) in tandem with these cheek-pieces also signals that an important shift had taken place in the way chariots were controlled. Quite a large number of antler cheek-pieces were also used at Zhangjiapo, with 26 found in one of the three major tombs that date to the ninth century BC (Fig. 8b). As all of these three tombs were equipped with chariots on their southern ramps, the owners were likely to have been drivers or owners of chariot teams and may have had extensive contacts with those non-Ji clans who, we suggest, were known to have been expert at managing horses. Another antler cheek-piece was found in a catacomb tomb, which is a burial-style typical of north-western clans (Falkenhausen, 2006, p. 207). The bronze cheek-pieces from Zhangjiapo are especially interesting as they take features of their 


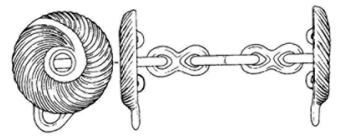

a

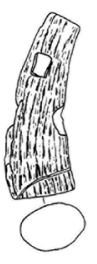

b

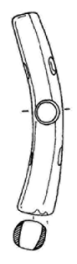

C

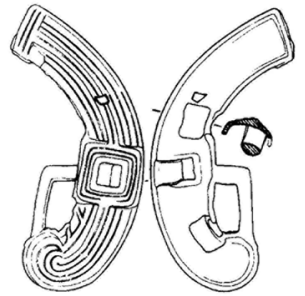

f

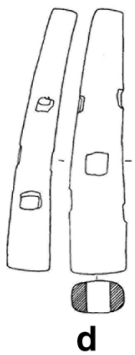



g

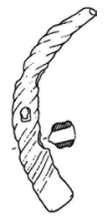

h

Fig. 8 Horn and bronze cheeckpieces from Zhou dynastic cemeteries at Fengxi and Zhangjiapo, at Xi'an, Shaanxi province. a bonze cheek-pieces and bit, Zhangjiapo, tenth century BC (after Zhongguo, 1999, fig. 166); b-d horn cheek-pieces, Zhangjiapo tenth to eighth centuries BC (after Zhongguo, 1999, fig. 247); e bronze cheek-piece, Fengxi, tenth to ninth century BC (after Lu, 1987, fig. 16); f-h bronze cheek-pieces imitating antler ones, Zhangjiapo ninth to eighth century BC (after Zhongguo, 1999, fig. 167)

designs from antler examples (including the cheek-piece on the left in Fig. 8e, from nearby Fengxi [Lu, 1987, fig. 16:3], a cemetery where attendants were also buried prone-a style that was common to the Mongolian Plateau during the late second millennium BC).

These examples from a cemetery of the Zhou clan illustrate the ways in which regional practices of horse management were introduced directly into the centre of the settlements and chariot troops of dynastic leaders by people with their own burial customs. And this practice ensured the continuity of two styles of cheek-piece: traditional northern examples in antler horn or bone alongside bronze ones developed out of the rod-shaped examples, often in a comma shape. The continuous use of both types suggests that new horses with new drivers familiar with the antler rod type were continually introduced among the polities, both of the Ji clan and of the non-Ji. 


\section{The Liulihe Cemeteries at Fangshan, Baifu in Hebei Province, and Zhangjiapo Near Xi'an}

The Zhou had despatched high-ranking members of their clan, the Ji, to set up the polity of Yan to control the region around Fangshan. There, an important cemetery at Liulihe southwest of Beijing offers us further information (Beijingshi, 1995). Geographically, this was a sensitive area, as raiders or invaders could move into it both from the northeast, and over the Jundushan Mountains from the Mongolian Plateau in the northwest,. The cemetery at Liulihe probably dates to the end of the eleventh century and into the tenth century BC, making it later in date in general than the important tombs at Shigushan and the first tombs of the Yu lineage. Two tombs have revealed some fine bronzes, a few with inscriptions naming the Yan elites. Narrow willow-leaf swords, typical of the Yu and also of the southwest, were also found here, as were a few beaded ornaments. Moreover, as in the cemeteries in Baoji, the ritual vessels came from a variety of different owners (Hwang, 2012), suggesting that they were seized by the Zhou to then give to their new allies. The people buried in the smaller tombs were less highly ranked, and from their various body positions we can suggest that they had diverse regional backgrounds. The skeletons of the main occupants in M22 and M105 are fragmentary or have disappeared (Beijingshi, 1995, p. 15, fig. 9, p. 33, fig. 22). However, both include an attendant, buried prone, who was likely to be among the many people who had moved south from the Mongolian Plateau (Rawson et al., 2020), perhaps even in the Shang period

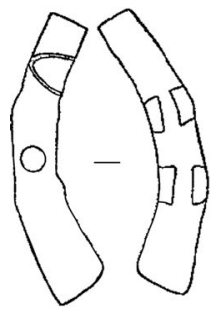

a

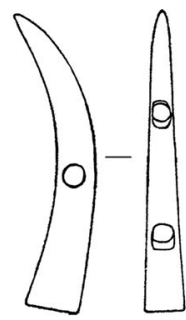

b

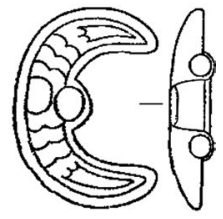

C

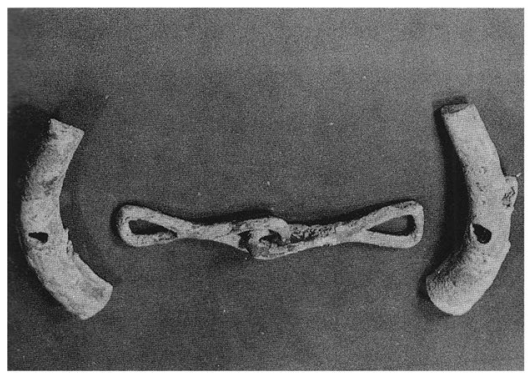

d

Fig. 9 Yan polity, founded by the Zhou, Beijing, with tombs from the cemetery at Liulihe. a bronze cheek-piece from M22; b horn cheek-piece from M105; c bronze C-shaped cheek-piece from tomb M53; d photo of the cheek-pieces and the bit from M22 (after Beijingshi, 1995, figs. 133:3, 4; 146:1; pl. 86) 
(Ji \& Zhang, 1993; Zhang \& Zhai, 2016). Both the Liulihe tombs, where ritually killed prone attendants were found, also contained narrow, curved cheek-pieces with the three holes (Fig. 9a, b). In M22 a pair of cheek-pieces imitates antler or horn in bronze (Fig. 9d). The cheek-pieces in tomb M105 were made of antler (Fig. 9b), and further examples were found in the chariot pit at the site.

Several other types of cheek-pieces were found in the Liulihe tombs, probably selected by people from different traditions of horse management who contributed to the chariot forces over a period of a century or so, each with slightly different ideas of best practice and the best kit. One of these cheek-pieces is shaped like the crescent moon, and it too has three perforations (Fig. 9c); the type seems to have been especially popular in the northeast, and turns up alongside cheek-pieces made of antler in a small group of three unusual tombs at Baifu near the Yan Mountains (Fig. 10a) (Beijingshi, 1976; Linduff et al., 2017, pp. 91-95). These latter tombs must have belonged to a small non-Ji clan, whose support the Yan polity may have sought. As well as a large number of varied weapons, some in Zhou style and others typical of the Arc, two of the tomb owners, a man and a woman, had a bronze helmet each (Fig. 10b); a similar but earlier helmet was found at Liulin in Shanxi

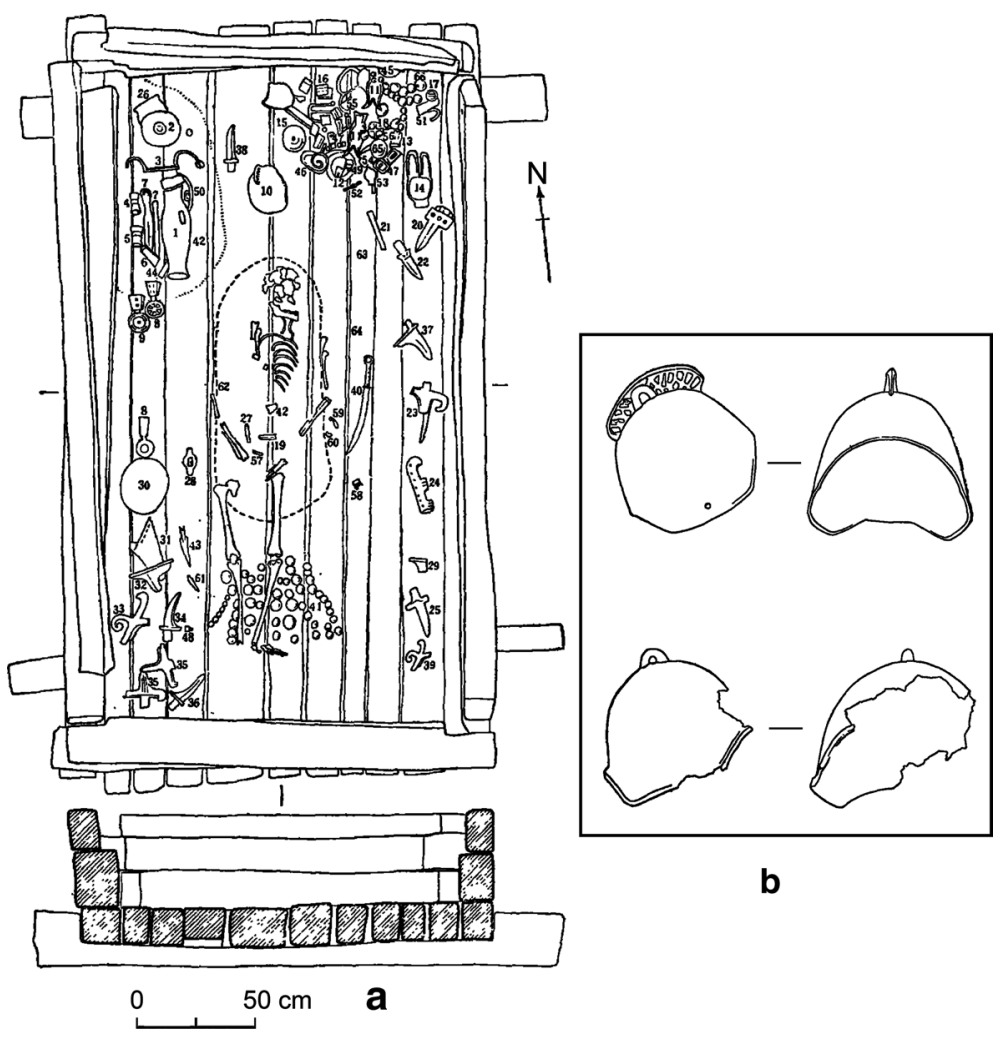

Fig. 10 a Plan of Baifu, Beijing, tomb M2; b two helmets from the site, tenth century BC (after Beijingshi, 1976, figs. 2; 10) 
province on the northern Yellow River (Yang, 1981, pp. 211-212, pl. 4:5). Although bronze helmets have been found further north (Honeychurch, 2015, p. 131, fig. 5.11) it is likely that there people more commonly used leather for helmets and armour (which were also made in bone and antler). When the northerners, as described by Cao Dazhi, exchanged horses for bronze with the late Shang (Cao, 2014), they may have been encouraged to replicate popular steppe objects, like helmets and bridle equipment, in bronze. The woman buried at Baifu had animal-headed daggers and also had bronze bosses around her feet and legs, originally on her boots or leggings; as in the Yu tombs (Fig. 6); this constitutes a form of dress unknown in the Central Plains. On the other hand, bronze chariot fittings indicate that this group valued and managed chariots in the Zhou manner. In addition, the Baifu tombs included some bronze ritual vessels cast at metropolitan centres, and these had been acquired without doubt from the Zhou, either as booty or as gifts (Beijingshi, 1976, pl. 2).

Another tomb of an individual from elsewhere was found at Liulihe. It has a most unusual structure, but one repeated at the $\mathrm{Ba}$ and Peng cemeteries in the central region of the Arc. The large rectangular tomb pit is about $7.7 \mathrm{~m}$ long and $5.3 \mathrm{~m}$ wide, with a coffin chamber at the centre. It has a slanting passage at each of the four corners (Fig. 11) (Liulihe, 1990, col. pl. 1). This very rare burial type has also been found in central southern China, which suggests that interactions with non-Ji clans from the Arc continued southwards, across several widely scattered regions (Hubeisheng et al., 2013). The Liulihe tomb was badly looted and the robbers left behind only the remains of shields and antler armour, which reinforce the interpretation that this was the tomb of a powerful outsider. The shields stood on the secondary ledge, against the inside wall of the tomb pit, and were decorated with bosses in the shape of human faces-some with aggressively sharp teeth. A bronze helmet, similar to those found at Baifu, was found in the tomb. Several very fine inscribed bronzes have been excavated; however, their long inscriptions, which refer to Zhou

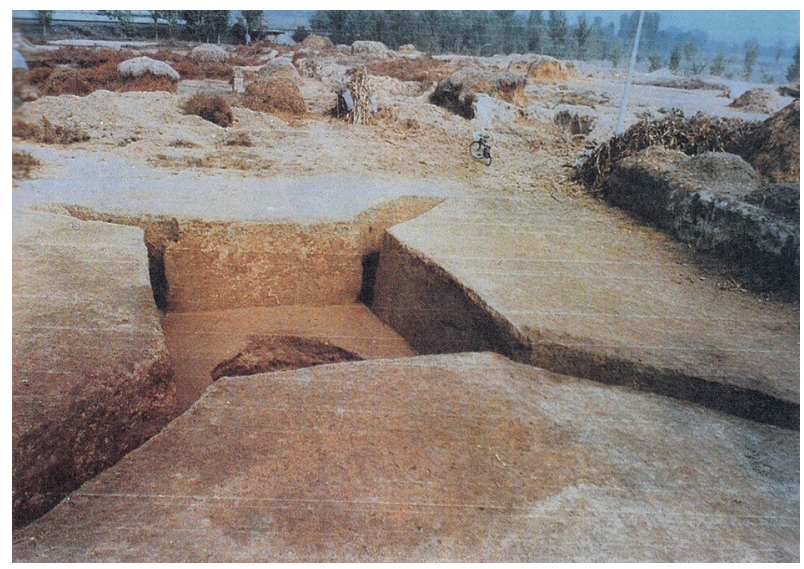

Fig. 11 Photo of tomb M1193 with four channels at the corners, Liulihe, Beijing, tenth century BC (after Liulihe, 1990, pl.1) 
elite activity, are somewhat incongruous among other contents of the tomb, and it is possible that these were either second-hand gifts or booty.

\section{The Centre, the Fen River and the Yellow River at Hancheng}

The politics in this central region, where the south-flowing Yellow River and its tributary, the Fen, form interlinked agricultural basins, were more complex than in the two other areas discussed (Fig. 1); this much is clear when we examine the cemeteries. Here, the long-term occupation of non-Ji clans as clients of the Zhou court probably continued down to the end of the Western Zhou period, and well into the eighth century BC. Two polities founded by members of the Zhou royal clan clearly acted as barriers to further movement south by peoples in the north. The most important was the Jin polity on the Fen River, founded by a brother of King Wu, who conquered the Shang. Even after the Zhou left their base in the Wei basin in eighth century BC, the Jin remained the dominant power here. Its two main excavated cemeteries include one of lower-level elites at Tianma-Qucun (Fig. 12), with tombs from the early tenth down to the eighth, or even the seventh century BC
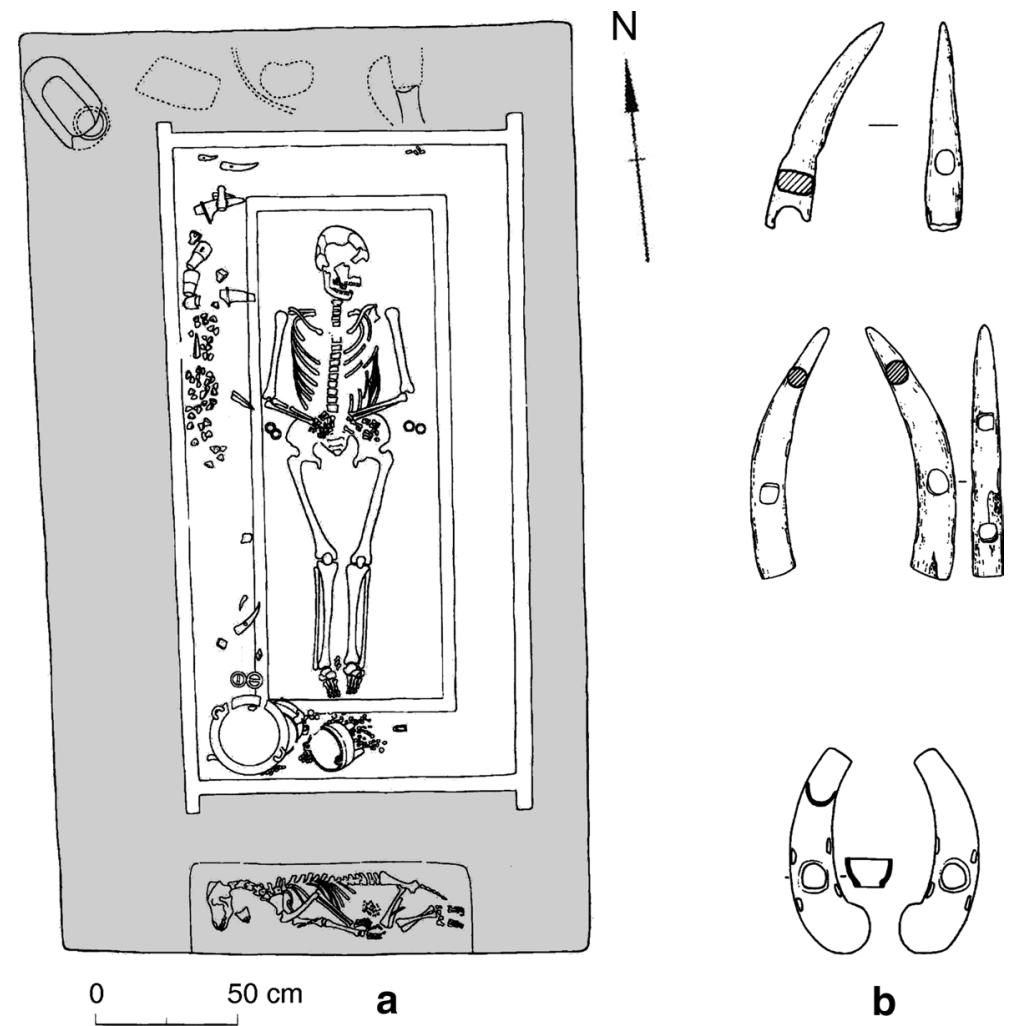

b

Fig. 12 a Plan of Tianma-Qucun tomb M6130, tenth to ninth century BC; b horn and bronze cheekpieces from the tomb (modified from Beijing \& Shanxisheng, 2000, vol. 2, figs. 470; 655) 
(Beijing \& Shanxisheng, 2000), and a cemetery for the Jin leaders and their consorts at Beizhao, with a further pair at Yangshe (Li, 2006, pp. 84-88). The tombs at Beizhao of the late tenth or ninth centuries BC have been partly looted, but large tombs of the ninth and eighth centuries BC escaped the robbers. For Beizhao, we only have preliminary reports and thus little information on horse equipment, although undoubtedly the lords owned both chariots and horses, as they had large chariot pits. Another branch of the Ji, the leaders of the Rui state, moved, in the late ninth century BC, from their original home in the Baoji area to the west bank of the Yellow River, where one of their cemeteries has been identified at Liangdaicun (Shaanxisheng et al., 2010).

More surprising have been the discoveries of two very large cemeteries for polities founded by non-Ji clans:the Ba at Dahekou in Yicheng county and the Peng at Hengbei village in Hengshui town (Rawson et al., 2020, fig. 19). The Ba occupied land east of the Jin polity, while the Peng polity was further south (Fig. 1). The tombs are generally orientated west-east and in the case of Peng some of the leaders were laid prone. Two of the most important tombs in these cemeteries (one in each) have the four slanting passages (Fig. 13), one at each corner, which we previously noted in an example at Liulihe (see previous section, Fig. 11). Both cemeteries are enormous, and the major tombs are extravagantly equipped, suggesting that the lords were very powerful and very probably exerted pressure on the Zhou. As the excavation of tomb M1 in the Ba cemetery, one of the earliest identified so far, is the most fully reported, we shall concentrate primarily on this example, while briefly referring to others (Xie et al., 2020a). This tomb is especially relevant here, as it includes clear evidence of the use of rod-shaped antler cheek-pieces and weaponry regarded as typical of the Northern Zone.
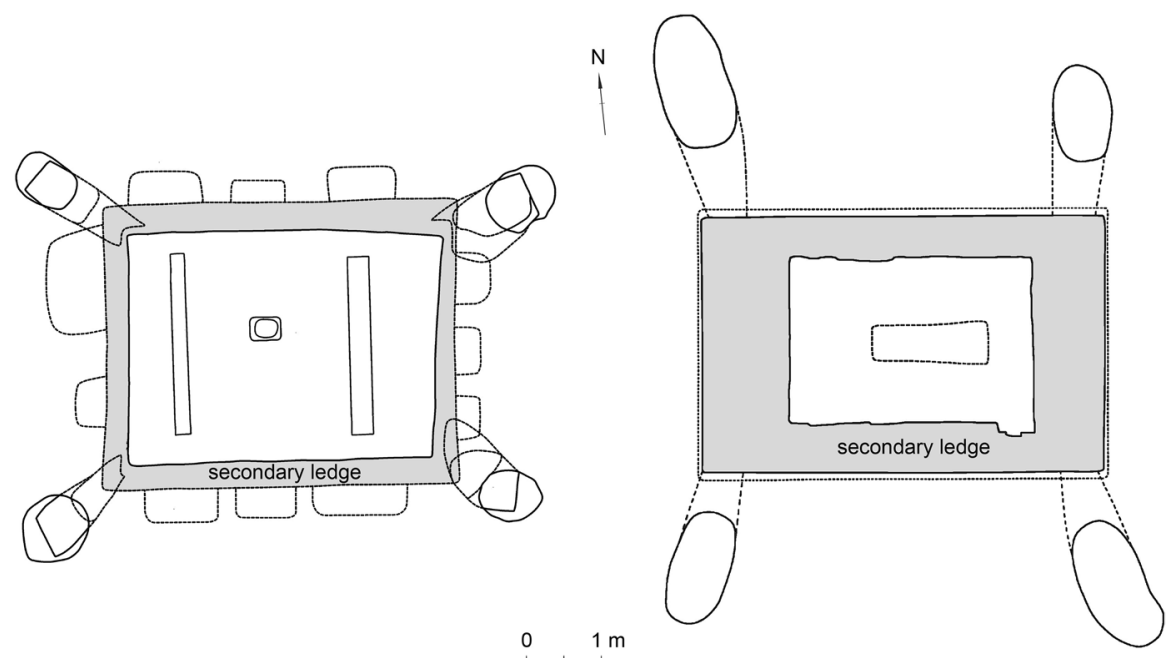

Fig. $13 \mathrm{Ba}$ and Peng tomb outlines with passages, tenth century BC. Left tomb M1 at Dahekou (after Xie et al., 2020a, fig. 3); right tomb M2158 at Hengshui, Shanxi province (modified from Xie et al., 2019, fig. 4) 


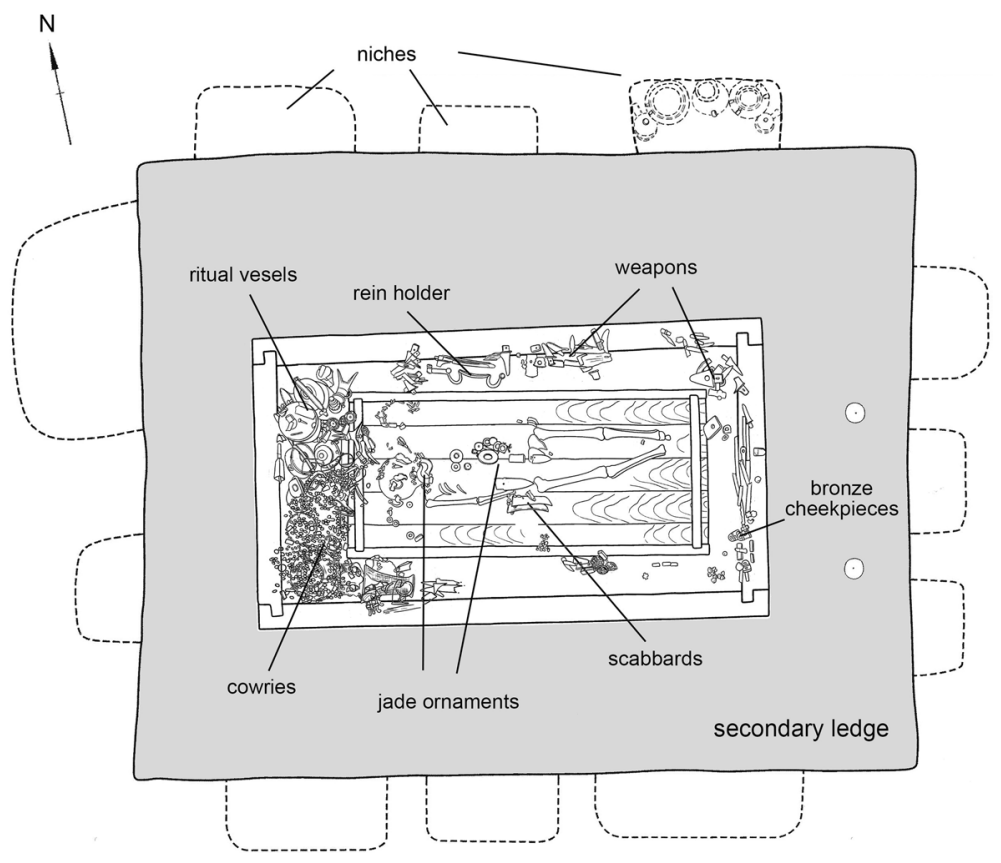

Fig. 14 Plan Ba tomb with niches, M1, Dahekou, Shanxi province (modified from Xie et al., 2020a, figs. $6 ; 9 ; 10)$

In addition to the four sloping passages, which are located high up the shaft, the Dahekou M1 tomb has eleven niches, similar to those at Shigushan (Fig. 5), above the secondary ledge around a central coffin chamber which held a single coffin (Fig. 14). Even more unusual are two lacquered wooden figures standing between the niches on the south side of the pit (Xie et al., 2020a, figs. 6; 7, upper plan). To date, these are the earliest examples of tomb figures in China. They may have provided an impetus to or model for the wooden attendant figures in a Rui polity tomb, M502, at Liangdaicun, which would indicate a form of cultural exchange between members of very different polities in the area (Shaanxisheng et al., 2010, pls. 52-54).

The Ba lord in M1 at Dahekou, as we saw from the tomb construction, shared a background with people buried both at Liulihe and at Shigushan near Baoji. He also owned weapons, including willow-leaf swords, shafted axes and a bird-headed staff, comparable with those employed in the Yu polity (Xie et al., 2020a, figs. 88, 91:4, 96, 98, 99, 101), as well as a curved axe, also seen at Lingtai (Zhang, 2014); and, as in the large tomb at Liulihe (Liulihe, 1990, p. 103, fig. 127), the tomb displays several large shields, in this case lacquered. The extraordinary number of bronze ritual vessels - 71 in all - far exceeding the number required for standard ceremonial banquets, demonstrates close links with the Zhou court that the owner (or, at least those who buried him) wished to display to the Zhou, to his ancestors and to his clan. The vessels are of a very high quality, several having been cast with well-composed and 
Fig. 15 Two types of cheekpieces from Ba tomb M1, Dahekou, Shanxi province, tenth century BC. $\mathbf{a}$ in bronze for a noseband; $\mathbf{b}$ in antler (after Xie et al., 2020a, figs. 105:5; 128:5)

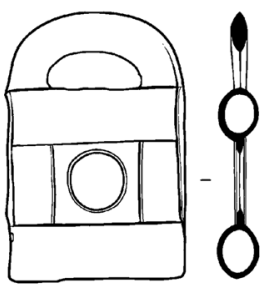

a

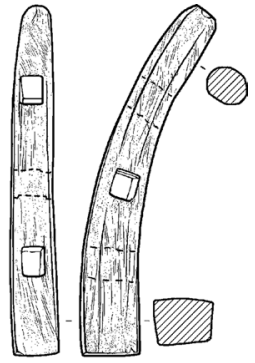

b

written inscriptions. Such work is likely to have originated in metropolitan workshops under the direction of experienced overseers.

The tomb occupant had very evidently been a leader of chariots and horses. He was interred with 237 bronze chariot-fitting or horse-tack elements, as well as a significant number of bone and antler cheek-pieces. Some of the bronze cheek-pieces are rectangular in shape, with the loop for the nose band, mentioned earlier (Xie et al., 2020a, fig. 105:5). The deceased was buried with eight of these: four pairs (perhaps for a single chariot with four horses), representing late versions of the early type (Fig. 15a). But he also had 18 antler cheek-pieces with the usual pattern of three holes in two different planes, already discussed (Figs. 15b, 7a-c). One of his immediate descendants took up the new type of bronze cheek-piece cast in a comma shape derived from the antler rod form (Xie et al., 2018a, p. 251; Fig. 20). Additional contacts are suggested by the lord's ownership of an archer's thumb ring in bone (Fig. 16a) (Xie et al., 2020a, fig. 129:5). This archery tool must have been widely used, but probably more commonly took the form of a simple leather covering of the thumb and part of the hand. The Ba continued to occupy this area down

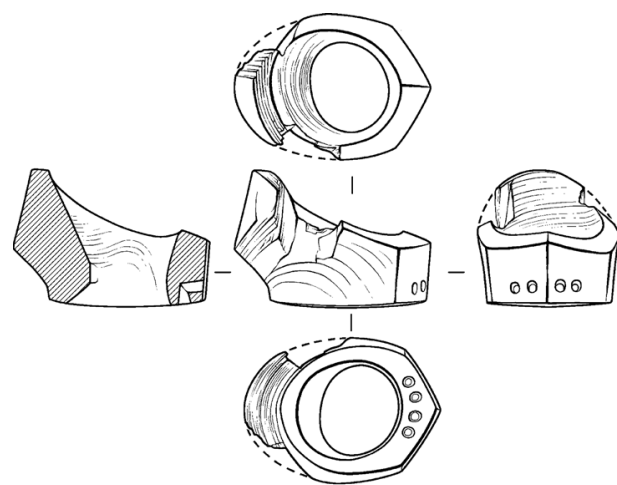

a

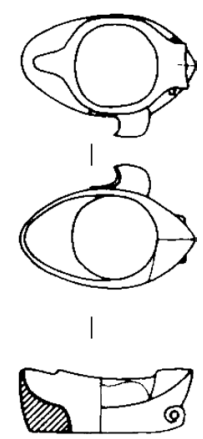

b

Fig. 16 Two thumb rings. a bone from tomb M1, Dahekou, Shanxi province, tenth century BC (after Xie et al., 2020a, fig. 129:3); b jade from Liangdaicun, Shaanxi province, eighth century BC (Sun et al., 2007, fig. 27) 


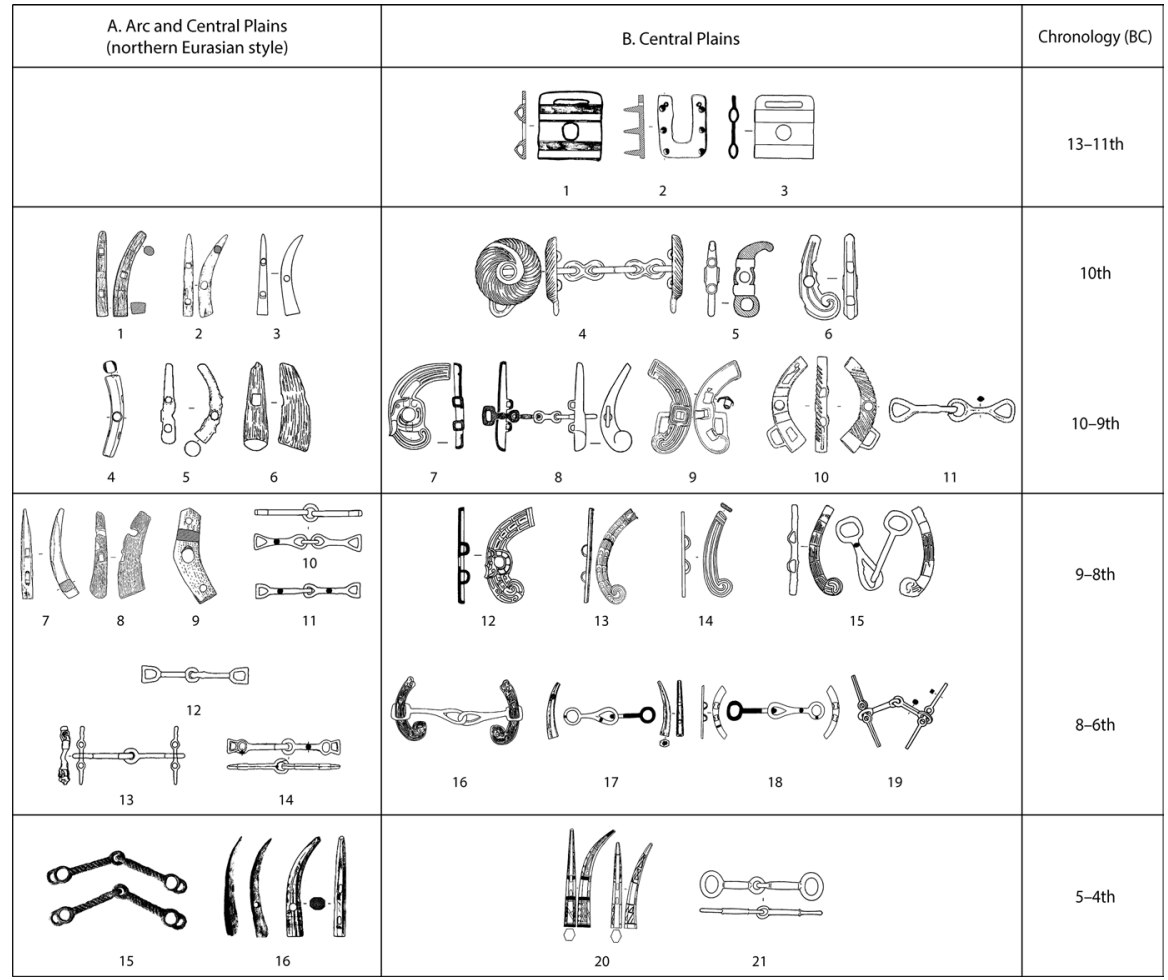

Fig. 17 Development of cheek-pieces and bits in the Arc and in Central Plains. Type A: 1 Dahekou; 2 Tianma-Qucun; 3 Liulihe; 4 Zhangjaipo; 5 Baoji, Rujiazhuang; 6 Shaolingyuan; 7 Sanmenxia; 8 Dahekou; 9-11 Xiaoheishigou; 12-14 Jundushan; 15, 16 Zhaitouhe; Type B: 1, 2 Dasikong; 3 Shigushan; 4 Zhangjiapo; 5 Baoji, Zhuyuangou; 6 Fengxi; 7, 8 Baoji, Rujiazhuang; 9 Zhangjiapo; 10, 11 Pingdingshan; 12, 13 Luoyang; 14 Liangdaicun; 15 Dahekou; 16 Liangdaicun; 17, 18 Tianma-Qucun; 19 Bengbu; 20, 21 Marquis Yi of Zeng's tomb

to the eighth century BC, using both antler cheek-pieces and Zhou-style bronze tack throughout (Fig. 17, A8, B15) (Xie et al., 2020a; Zhu et al., 2019). While we will not discuss the Peng tombs in detail, we include them in our table of Ji and non-Ji burials (Table 1) to illustrate the strength in the Fen River basin of the non-Ji clans alongside their Ji contemporaries (Khayutina, 2017b).

The high social value of horses in the region is also very clear in the tombs of the Rui lords of the Ji clan at Liangdaicun, whose period of greatest activity was in the ninth and eighth centuries BC. Many tombs display bronze horse armour along with small sections of bronze armour used for personal protection (Shaanxisheng et al., 2010, pls. 125-131). All of these pieces were forged rather than cast, using a technology that we have noted already as non-native to the Central Plains, and suggestive of technologies and customs introduced from further northwest (Chen et al., 2009). We can see that the lords of the Jin and Rui states, as well as their consorts, adopted some of the decorative items used by the Ba that were ultimately derived from the steppe (Novozhenov, 2012, p. 18; Fig. 1). These include hanging pendants 


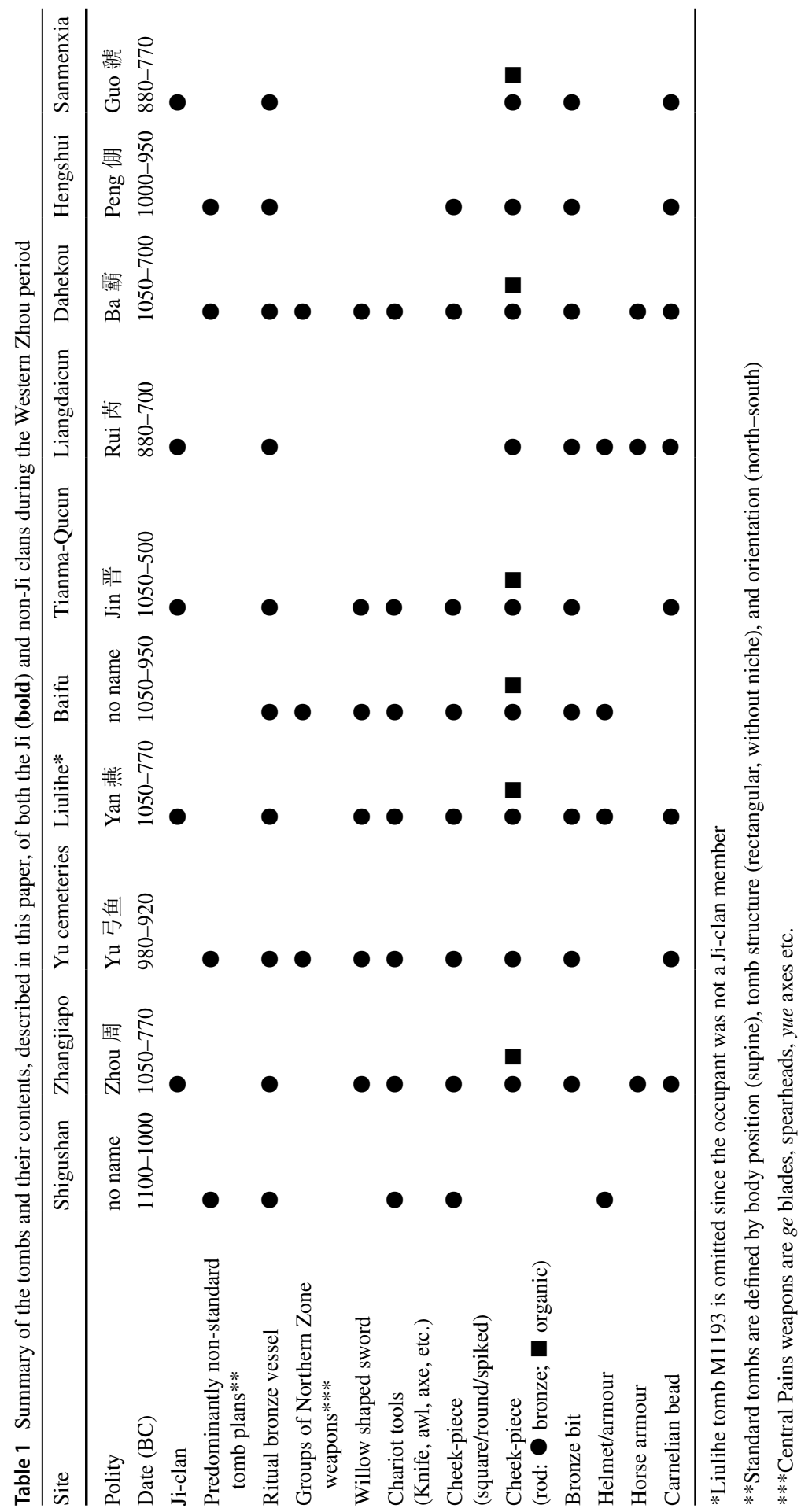


in jade, carnelian and faience. The Ba lord in Dahekou M1 owned early examples of these (Xie et al., 2020a, pp. 275-281). More extravagant hangings with multiple types of beads and jades appear in many of the later tombs of the Ji clan members, not just in the Jin and Rui polities nearby, but also further east in the Guo and Ying polities along the Yellow River where it runs east (Henansheng \& Pingdingshanshi, 2012; Henansheng \& Sanmenxiashi, 1999). Here also we find antler and bone rodshaped cheek-pieces as well as bronze ones (Fig. 17, B6).

A Rui lord of the eighth century BC at Liangdaicun also had archer thumb rings, but in gold and jade (Fig. 16b), and he and his consort had exceptionally ostentatious displays of beads and jades (Huang, 2013; Rawson, 2013). His numerous gold ornaments, as well as a gold belt (Sun et al., 2007) indicate a new taste for gold that was likely brought from the north by the Ba, among others (Xie et al., 2018b, pl. $40: 3,4)$. His possession of a belt in gold suggests an even closer relationship with more distant steppe lords who prized such display (Chugunov et al., 2010). This development is a very important sign of the growing exchanges with Inner Asia, as materials and technologies from the north reached the Central Plains, probably accompanying northern horses. In return, the Zhou cemented their relationships with fine ritual bronzes as part of this exchange. From the Han period (206 BC-AD 220), if not earlier, the search for horses led dynastic leaders to contribute much more in silk, lacquer and bronze, often presented as gifts (Twitchett \& Loewe, 1986, p. 397, table 10; Hansen, 2012, p. 16). By the ninth and eighth centuries BC, the search for horses had become a conspicuous factor in the exchange of materials and technologies between Eurasia and the Central Plains.

\section{Changes in the Ninth to the Fifth Century BC}

The collapse of Zhou power in the Wei valley, which the Zhou left in the eighth century BC, followed a prolonged engagement with the Quanrong or the Xianyun in the Arc and was accompanied by upheavals in the court (Li, 2006, p. 274). In the difficult years of the second half of the ninth century BC attempts at stability had been marked by major changes instituted in the offerings made to to the ancestors, sometimes termed the Ritual Reform (Rawson, 1999); but the ritual changes were probably just one aspect of a much larger crisis, during which relationships between peoples of the Central Plains, the Arc, and the steppe shifted fundamentally (Li, 2006, pp. 187-194). Major cultural reorganisation had taken place in the north, bringing to an end the domination of the Deer Stone-Khirigsuur (DSK) cultural complex across the Mongolian Plateau (Honeychurch, 2014), and this was accompanied by what may have been the introduction of the first extensive mounted horseback riding into this area of the steppe (Taylor et al., 2017). Significant climate issues around 850 BC (van Geel et al., 2004) almost certainly encouraged southward movement. Attacks by people with chariots are recorded in bronze vessel inscriptions, and these exacerbated tensions among the polities on the Central Plains (Li, 2006, pp. 147-150). We can mark these cumulative changes not only in the Ritual Reform and Zhou departure from the Wei valley, but also in the phenomenon of large-scale movement of new peoples into the northeast: first those today named as belonging 


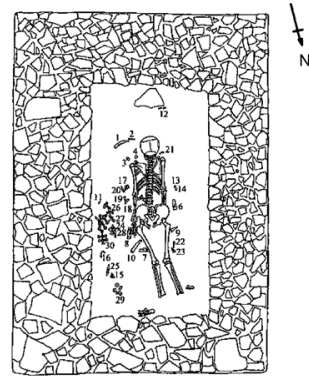

Xiaoheishigou

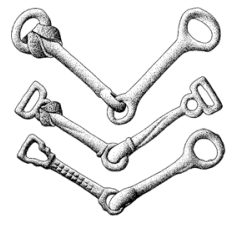

a

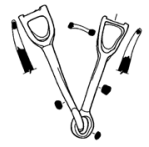

b

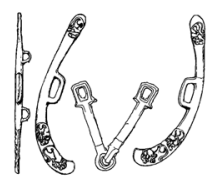

C



d

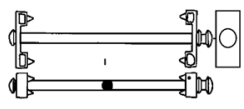

e

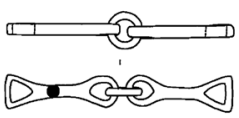

f

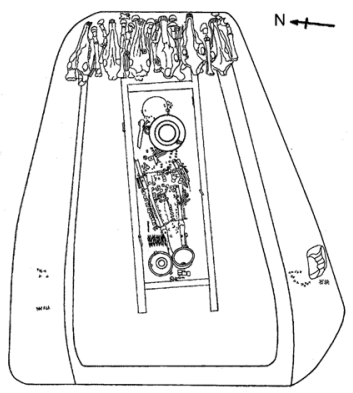

Jundushan<smiles></smiles>

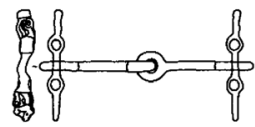

g

h
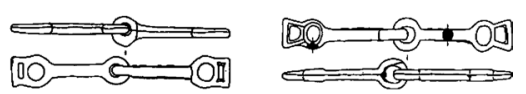

i

j

Fig. 18 Comparison of tomb plans and cheek-pieces from three sites. Tomb plans: left Xiaoheishigou tomb M11 (after Nengmenggu and Ningchengxian 2009, fig. 284); right Jundushan tomb M18 (after Beijingshi, 2010, fig. 42); cheek-pieces and bits: a Arzhan 1, Tuva Republic (after Grjaznov, 1984, fig. 12:1); b, c Arzhan 2, Tuva Republic (after Chugunov et al., 2010, pls. 141:2; 142:9); d-f Xiaoheishigou (after Neimenggu \& Ningchengxian, 2009, figs. 285; 304; 321); g-k Jundushan (after Shulga, 2015, fig. 64)

to the Upper Xiajiadian cultural group of the ninth to eighth centuries BC, known for their swords, mirrors and unusual horse tack (Linduff et al., 2017, pp. 104-118; Liu \& Xu, 1975; Neimenggu \& Ningchengxian, 2009); followed by people whose burials are known from cemeteries south of the Yan Mountains, on the slopes of the Jundushan, and which date to the seventh to fifth century BC (Beijingshi, 2010; Shulga, 2015). The tombs of both groups appear highly unusual and do not belong within Central Plains traditions (Fig. 18). Those of the Upper Xiajiadian are varied; many make use of stone structures, a typically northern Eurasian tradition (Gosden et al., 2019; Taylor et al., 2019) that is associated with early pastoralists, and used 
much earlier in the northeast over many millennia (Peterson \& Lu, 2013). The highranking tombs at Jundushan, which are primarily laid east-west, are very different: they have a coffin at the centre of a broad sunken space, which narrows from a wide rear towards the other end, and was covered with stones. Importantly, these latter tombs include an array of animal heads, a longstanding funerary tradition linked with steppe cultures (Piggott, 1962). The occupants here obviously valued bronze animal plaques, with which they adorned their clothes and which they hung from their belts. Some of these interments preserve evidence of a bronze belt system involving double plaques with a slot through which a belt passed-a device widely used in South Siberia and the steppes of Kazakhstan. In some tombs, the belts carried simplified forms of the decoration seen among the belts at Arzhan 2 in the Tuva Republic. While those tombs have been described as belonging to a Scythian political empire (Taylor et al., 2020), we prefer to recognise pronounced material similarities as part of a shared culture and follow the term Scytho-Siberian, as used by Di Cosmo (2002, pp. 32-35; see also Beijingshi, 2010, vol. 3, p. 1230, fig. 721; Chugunov et al., 2010, pl. 29; Shulga, 2020; cf Taylor et al., 2020).

The people carried daggers and axes. Bronze bits and cheek-pieces among the Upper Xiajiadian show varieties of improvisation and innovation in managing horses, perhaps stimulated by plentiful available bronze, and combined both bar-shaped and jointed metal bits with different kinds of cheek-pieces, including quite a number made of antler (Neimenggu \& Ningchengxian, 2009, pp. 352-355) (Fig. 18d-f). At Jundushan, bronze bits with stirrup-shaped ends, paired with bronze or organic cheek-pieces (Shulga, 2015, fig. 23) (Fig. 18g-k), are of the same style found at Arzhan 1 and 2 (Fig. 18a-c) (Chugunov et al., 2010; Grjaznov, 1984). There, too, bronze bits were used with antler or bronze cheek-pieces to which they were tied (Horvath, 2020). Neither the people of the Upper Xiajiadian nor those at Jundushan were buried with chariot fittings, and we may conclude that they probably owned light carts and may also have been riders. In the light of the similarities of the belt plaques and the bits with those at Arzhan 1 and 2, it is likely that the people at Jundushan had strong connections with the Mongolian Plateau and South Siberia. That the Zhou adopted neither these stirrup-shaped bits, nor those of their predecessors among the Upper Xiajiadian people, is a sign that there was little or no exchange between these groups and the people on the Central Plains. This is an important contrast with the impact that earlier non-Ji clans had had among the Zhou polities. At the same time, ritual vessels in both tomb areas are very limited and seem to be random acquisitions; they do not offer sets for ceremonial banquets. Those that do appear may have been acquired by raiding, or the tomb occupants may have in life discovered several of the many vessel hoards that were buried in the area at the point when the power of the Yan polity was declining (Beidong, 1974; Qi, 1979). In other words, these regional groups, who had arrived in the northeast, had much less interaction with the Zhou and do not seem to have been either their clients or their allies.

Around the same time, over the ninth to seventh centuries BC, with steppe-related groups moving into the northeast, the Zhou polities made their own changes to horse equipment (Fig. 19), perhaps stimulated by these developments. From the late second millennium BC, the Zhou had switched from square cheek-pieces to circular 


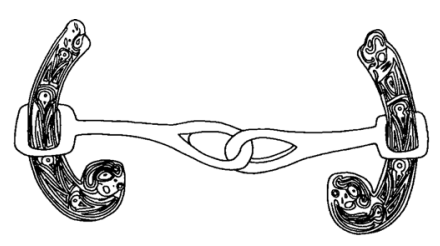

a



C



b

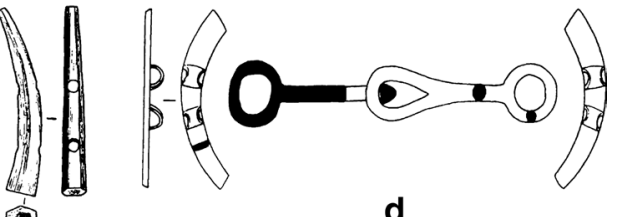

d

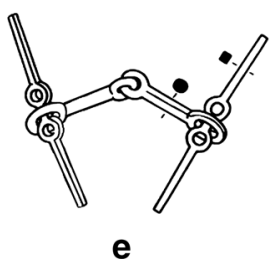

Fig. 19 Development and spread of bronze cheek-pieces cast by Zhou, with cheek-pieces thrust through the loops of the bits. This simplification happened as the new types of bronze bit spread in the eastern steppe (Fig. 17). a Liangdaicun, Shaanxi province, eighth century BC (after Shaanxisheng et al., 2010, fig. 61:1); b Guojiamiao, Hubei province, eighth to seventh century BC (after Xiangfanshi et al., 2005, pl. 38:3); c, d Tianma-Qucun, Shanxi province eighth to seventh century BC (after Beijing \& Shanxisheng, 2000, fig. 560); e Bengbu, Anhui province, sixth century BC (after Anhuisheng \& Bengbushi, 2013, fig. 69:4)

ones, and then again to larger comma-shaped versions, with still others imitating antler (many of which are likely to have required the bits to be tied to the cheekpieces: Fig. 7) (Shao \& Shi, 2018, 2019; Wu, 2002). But, by around 850 BC, when the steppe peoples at Arzhan 1 started to use their stirrup-shaped bits (Grjaznov, 1984) and the Upper Xiajiadian people had already moved into the northeast, significant changes also appear in the cheek-pieces used among the polities on the Central Plains. Among the Jin at Tianma-Qucun, as well as in the Rui state, the ends of the bits used for tying them to the cheek-pieces were greatly enlarged, enabling narrow versions of the earlier cheek-pieces to be run through their centres (Takahama, 2020, fig. 9). This method of assembly is more stable and efficient than tying the cheekpieces to the bit, which typically caused heavy wear on the connecting elements (Fig. 19). Simplified forms of cheek-pieces and bits (which only became popular elsewhere in Eurasia slightly later: Dietz, 2006) spread across the Zhou realm, and were widely used down to the end of the sixth century BC.

Meanwhile, groups of non-Ji clans (who were given the umbrella name of Rong by the leaders of the central states) played an increasing role in the politics of the next few centuries on the Central Plains. They may have been the driving force that led to new efforts to acquire horses (Shaanxisheng et al., 2018). A new form of cheek-piece carved from bone or antler had been introduced with the larger bits. 


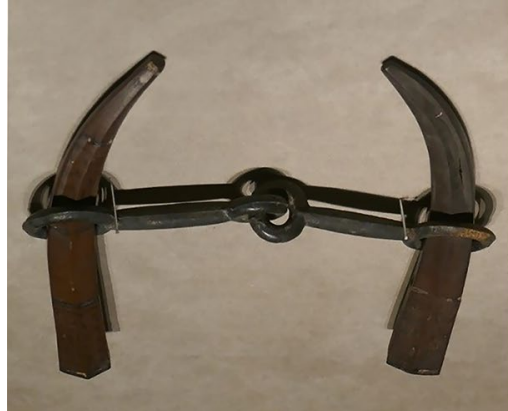

a



b

Fig. 20 Antler cheek-pieces. a from the tomb of the Marquis Yi of Zeng, 433 BC, Hubei province (photo by Jessica Rawson); b from Rong tombs at Zhaitouhe, Shaanxi province, fourth century BC (after Shaanxisheng et al., 2018, col. pl. 64)

This now became standard (Figs. 19c, 20a), and it followed the new system, being inserted into the two end-loops of the bit, requiring only two holes, not three. Antler now often replaced the slender bronze cheek-piece, a clear change in fashion. Major tombs containing these include those of the Jin state (Shanxisheng \& Taiyuanshi, 1996, fig. 62:2), those of many other high elite members of the central states, and also those of the powerful southern state of the Marquis Yi of Zeng at Sui County, dated to 433 BC (Fig. 20a).

It is very likely that the reversion to antler or bone cheek-pieces can be attributed to the members of the Rong, as they now formed small settlements or polities among the central states themselves. The few excavated tombs of the Rong show their own continued use of the Inner Asian forms of bone and antler cheek-pieces (Shaanxisheng et al., 2018, col. pls. 64, 65) (Fig. 20b). These cheek-pieces were also standard among the people who moved in from the north across the Arc at its northwestern end. A significant range of such horse equipment is found in their tombs in present-day Ningxia province (Xu et al., 1993). These changes, occurring from the ninth and eighth centuries BC onwards, were probably consequences of the widespread movement of people, many of them riders, who, unsettled by climatic/environmental change were attracted by the possibilities offered by the upheavals and uncertainties on the Central Plains. The Chinese histories, the Annals of the Spring and Autumn with the Zuo Zhuan commentary, give ample evidence that the Rong, and others named the $\mathrm{Di}$, intervened in the almost continuous warfare, engaging in both alliances and attacks, and generally made use of the destabilisation that followed (Di Cosmo, 2002, pp. 108-116; Durrant et al., 2016).

\section{Discussion}

The relations of the agricultural peoples of the Central Plains with non-Ji clans were clearly complex, particularly during the first half of the Western Zhou period (c.1050-850 BC), and the burial record across the Arc region as a whole preserves 
evidence for high-status individuals from a number of different clans. The majority, as we have seen, had apparently been offered and had accepted large numbers of high-quality ritual vessels to, as we may surmise, cement relationships. These were gifts of huge material and symbolic value and suggest that the deceased were clients or allies of the Zhou. The management of such relationships appears to have differed across the three areas described (Fig. 1). The people in the western Wei valley appear to have been exceptionally well-rewarded. But the evidence we have to date from dynastic Zhou cemeteries at Liulihe, near Beijing, and Zhangjiapo, at Xi'an, is rather different. Here a variety of people were buried at both cemeteries, suggesting that they had been drawn into the society, or perhaps into the fighting forces, of the Zhou state. Alongside the Yan polity, the tombs at Baifu indicate that a very small clan had also moved in, perhaps independently, and had managed to receive or otherwise acquire ritual vessels. The cemeteries of the $\mathrm{Ba}$ and Peng in the central region of the Fen are of remarkable size, which seems likely to have been a consequence of their accommodation within the Zhou realm over a long period of time, as they were located not far from the major Jin polity (Khayutina, 2017b).

Despite their differences, these three sub-regional Arc groups shared some forms of tomb structure. In particular, they had the same types of weaponry, such as willow-leaf swords, shafted or shaft-hole axes, curved axes, and the bird-headed staff. A central factor in this exploration of new materials and technologies brought into central China was that the non-Ji clans, who arrived over many decades and even over nearly three hundred years, had their own direct contacts with areas here generally identified as being in Inner Asia. In all three groups of tombs discussed (Table 1), forged bronze, shields, bosses on leggings or boots, helmets, bone or antler plates for armour, and beaded ornaments indicate contacts with practices and technologies in distant regions of northern Inner Asia (Rawson, 2013).

Horse equipment offers evidence of at least four different moments of contact over time, mediated by the non-Ji clans, with the horse breeders of the north (Fig. 17).

1. At Baoji we see a clear moment of change from the early first stage, which had started in the late Shang, continuing with the use of square cheek-pieces with nose band slits (Fig. 5), to an innovation in the tenth century BC, with a bronze form of the rod antler cheek-pieces with three holes (Fig. 7d, e), which marks stage 2.

2. The tenth century BC must have been an important moment for new contacts with the steppe or the northern parts of the Arc, with antler and bone cheek-pieces employed also in the central area around Xi' an and the northeast. The narrow antler type with three holes dominated this second stage, with different modifications in bronze effectively adopting the outlines of the steppe cheek-pieces (Figs. 7d-g, $8 \mathrm{e}-\mathrm{h}, 12 \mathrm{~b}$ ).

3. The third stage followed political and military upheavals that affected a large region from the late ninth century $\mathrm{BC}$, and were concurrent with the Ritual Reform (Li, 2006, pp. 141-192). At this time, new invading groups brought bronze bits with stirrup-shaped ends to attach to cheek-pieces, as at Xiaoheshigou (Fig. 18d-f) and Jundushan (Fig. 18g-k). These are forms that are also known from South Siberia, especially at Arzhan (Fig. 18a-c). And within the Zhou poli- 
ties a new arrangement drew the cheek-pieces through enlarged holes at the ends of the bit (Fig. 19).

4. The multiple political and social changes in the late ninth and eighth centuries BC set the stage for the upheavals of the Eastern Zhou period, when small groups of the Rong settled among the Zhou polities, introducing a new wave of interest in antler and bone cheek-pieces (Figs. 18c; 19).

As we summarise in Fig. 17 and Table 1, at all periods, some antler, bone, or occasionally wooden, cheek-pieces continued in use even though bronze ones were widely available on the Central Plains (Figs. 7, 17). As both antler and bronze examples were buried concurrently as late as the eighth century BC in the same cemetery, for example the Guo cemetery at Sanmenxia (Henansheng \& Sanmenxiashi, 1999, p. 104, fig. 90, p. 204, fig. 155:1, p. 208, fig. 157:10) (Fig. 17 A7) or the Ba cemetery at Dahekou (Zhu et al., 2019, fig. 2:3, 4; Xie et al., 2020b, fig. 60:7) (Fig. 17 A8, B15), the antler cheek-pieces suggest that members of regional groups, familiar with such horse equipment, continued to be employed managing horses in several different polities.

Throughout these changes, we see that Zhou polities themselves also deliberately adopted or adapted northern types of horse equipment. At the same time, they presumably also acquired horses, and those who could manage horses and who had knowledge of horse breeding, raising, training, and care. In other words, the small technical details of the horse bridles and their relation to changes in horse management in Inner Asia and further west confirm Zhou interests in horses from the north and their reception of non-Ji clans, who brought horse equipment and horses trained up with such equipment. Bridles and the changing types of the cheek-pieces, especially those made from antler or horn, provide us archaeologically with significant proxies for contact with people from Inner Asia. It seems clear the such people must have interacted with non-Ji clans on the northern edges of the Central Plains, and were part of the system that guaranteed the arrival of northern horses. If we wish to see the developing relationships between the non-Ji clans and the Zhou in more transactional terms, we can summarise our argument as suggesting that the outsiders gained land and a wealth of bronze, and thus status, within the ritually-framed organisation of the agricultural basins; the Zhou dynastic leaders turned these potential enemies into allies and in doing so, they gained fighters and horses. Additional benefits included new materials and technological exchanges, with the introduction of gold, iron, forging and, in due course, a wide range of daggers, swords and mirrors, which arrived along with the drivers who brought the horses.

As in later periods of East Asian history (Di Cosmo et al., 2018), major changes in the climate and environment of desert and steppe regions, such as prolonged intervals of wetter conditions, might have regularly altered pastoral social and ecological dynamics, allowing people to move south from the steppe with greater ease. Climate and environmental stimuli for population movements across the steppe and the Arc are an interesting avenue for future inquiry, but they require much more study to elucidate the detail related to the cases laid out here (Di Cosmo, 2020; Huang et al., 2003). On present evidence, we see that people moved south periodically. As they did so, peoples from the Arc not only settled near the Central Plains but were also 
drawn into close association with early Zhou societies. We argue that the associations we have described were above all driven by Zhou need for strong horses for the following reasons.

The Central Plains, whose great agricultural abundance supported the dynasty, was not an ideal environment for herds of horses.Yet, from the numbers mentioned in bronzes inscriptions, we know that the activities of state demanded large numbers of the animals (Wu, 2013, Table 1). Having evolved in the periglacial grasslands, horses are adapted to the cold, dry conditions of the steppe. As they rely on sweating to maintain a suitable body temperature, the combination of high temperatures and high humidity can introduce serious health challenges, such as heat stress and colic (Diakakis \& Tyrnenopoulou, 2018). In the summer, the Pacific Monsoon brings heavy rain across all of southern China, decreasing over the Central Plains and into the southern half of the Arc. The south is characterized by lakes and marshes, and large areas of paddy fields, with few areas of suitable habitat and high risk of insect-borne disease. In the Central Plains, some high humidity and severe temperatures pose another considerable threat to horse breeding. Today, around Xi' an (the early Zhou administrative centre), the July temperature may be $40^{\circ}$ centigrade, with $100 \mathrm{~mm}$ of rainfall and an average humidity of over $70 \%$. Under these conditions, would-be horse breeders may have faced high mortality and low fertility among their herds, especially by comparison with northern zones.

In addition to climate and environment, horse breeding in Central China also introduces nutritional deficiencies. Horses require certain minerals and vitamins. Among the best-studied of these is selenium, essential for muscle growth (Fonseca et al., 2016), a nutrient obtained through plant consumption, and determined by an area's underlying geology. The geographical distribution of selenium has been

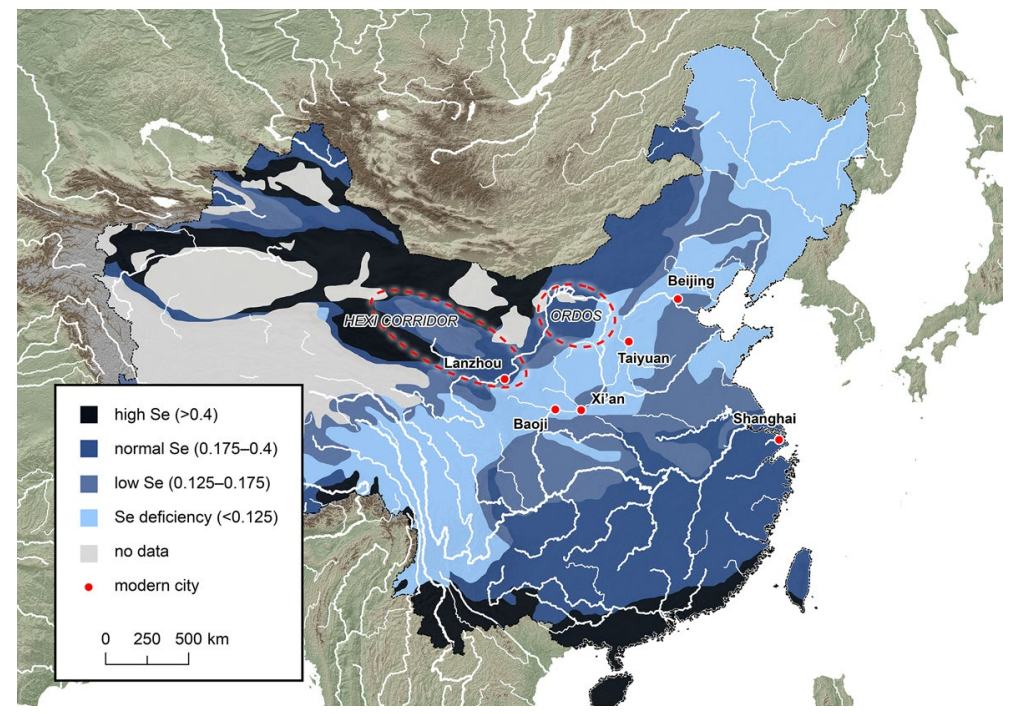

Fig. 21 Distribution of soil selenium concentration $(\mathrm{mg} / \mathrm{kg})$ in modern China. The circled areas were favoured by later emperors for ranches (modified by Limin Huan from Sun et al., 2016, fig. 1) 
carefully studied across modern China (Fig. 21) as it has significant impacts on human health (Li et al., 2014; Marek, 2019; Rayman, 2000). In south China, reasonable levels of selenium are available, as the heavy rains circulate minerals through the landscape (Sun et al., 2016), but this area is poorly suited to horse breeding for other environmental reasons. For the Central Plains, and extending north and south along the regions covered by the Monsoon, greater rain increases selenium availability, but this selenium is rapidly volatilised in the summer heat, encouraged by microorganisms. Consequently, within the borders of modern-day China, only in the north and northwest areas (where the southern Monsoon generally does not reach and the summer temperatures as well as the humidity are lower), are lands with adequate selenium found. Areas with suitable selenium extend into the Mongolian Plateau and South Siberia, including the Altai Mountains, regions that boast extensive grasslands for pasture. The belt of land with lower rain and high volatilisation-which spans the heart of China's early dynastic political and economic power base-therefore suffered from a chronic nutrient deficiency that may well have hampered efforts to breed strong horses. Another key limitation on horse breeding was agricultural land-use practices. In both the Shang and the Zhou, land across the Central Plains that was not crop farmed was marshy and prone to flooding, or covered in scrubland and forests. The population was not accustomed to joint farming of herded animals and crops and was, at all periods for which we have written evidence, reluctant to replace agriculture with pasture (Grass, 2019).

This covariance between climate, habitat, and nutritional deficiency introduced structural limitations on raising large herds of strong horses on the Central Plains. When faced by chariots and, later, cavalry from the north, the dynasties had either to seek horses from areas with better pasture in today's regions of Mongolia, Inner Mongolia, the Ordos region and along the Hexi corridor and the higher lands of Xinjiang, or to try to create ranches in the northwest. This imbalance had large-scale geopolitical consequences: later historical texts document the extensive efforts made by Chinese states to acquire and pasture northern horses to fend off the mounted forces from northern Eurasia (Beckwith, 2009; Di Cosmo, 2002, pp. 83-90; Shulga, 2020; Hansen, 2012, pp. 80-82; Skaff, 2012, pp. 257-271; Tackett, 2017, pp. 78-80). For example, when the Ming emperors, in turn, were faced by continuous pressures from the Mongols, they attempted to persuade the peasants to herd horses; but the costs for peasants were too great and their horses were too weak. The emperors, as many before them, had to turn back to acquiring horses from the north (Brook, 2019, pp. 128-131; Grass, 2019).

The search for a continuous supply of horses from the north was initiated during the late Shang and Zhou dynasties and became a major aspect of warfare, as northerners from the Arc moved as clients or allies to lands on the northern edges of the Central Plains. Given the very different material cultures of the northerners, with their own contacts with Inner Asia, the horses that they brought were often managed with antler cheek-pieces in steppe style, accompanied by artefacts of gold, iron, forged bronze and beaded ornaments, technologies that were rapidly adopted and adapted by the Zhou polities (Rawson, 2013). Although from the ninth century BC, with its increasing climatic problems (van Geel et al., 2004), pressure on the Wei Valley by horse-owners from the north led to conflict and further incursions 
over the long term, dynastic leaders continued to seek horses from the north and especially the northwest. The development of prolonged, formalized conflicts with steppe groups from the Mongolian Plateau interrupted the important horse exchange across the Arc. As we know from the famous story of the blood-sweating horses of Ferghana (Kelekna, 2009, pp. 145-147), one of the motives of the Han move into the Western Regions (present-day Xinjiang) was to find not only allies but horses, so as to adequately respond to a major deficit caused by prolonged conflicts with the Xiongnu (Cooke, 2000). Such persistent, enduring demands for horses became the foundation of long-term exchanges, with silk, lacquer and metalwork offered to horse breeders outside of the hostile steppes, including Central Asia and the Himalaya. These exchanges helped catalyze important social and economic changes across China (Zhang et al., 2018).

Acknowledgements We have benefited greatly from collaboration with Konstantin Chugunov of the State Hermitage Museum, St Petersburg during his visit to Oxford in January 2019, funded by Merton College and Ian Taylor. Professor Chechushkov of Pittsburgh University provided important information on horse harness. Research that underpins the wider discussion was first carried out with a Leverhulme Trust Grant F/08 735/G, which enabled collaboration with the School of Archaeology and Museology at Peking University. Significant support for research for the paper, including visits to China, was offered by Peking University and the China Academy of Art, Hangzhou. We are grateful for comments by two reviewers whose suggestions we have incorporated.

Funding Funding for Dr Huan was offered by Merton College, Oxford.

Availability of data and material All materials used in this paper are publicly accessible.

Code availability Code availability (software application or custom code)

\section{Declarations}

Conflicts of interest No conflict of interest.

Open Access This article is licensed under a Creative Commons Attribution 4.0 International License, which permits use, sharing, adaptation, distribution and reproduction in any medium or format, as long as you give appropriate credit to the original author(s) and the source, provide a link to the Creative Commons licence, and indicate if changes were made. The images or other third party material in this article are included in the article's Creative Commons licence, unless indicated otherwise in a credit line to the material. If material is not included in the article's Creative Commons licence and your intended use is not permitted by statutory regulation or exceeds the permitted use, you will need to obtain permission directly from the copyright holder. To view a copy of this licence, visit http://creativecommons.org/licen ses/by/4.0/.

\section{References}

Allard, F., Erdenebaatar, D., Olsen, S., Cavalla, A., \& Maggiore, E. (2007). Ritual and horses in Bronze Age and present-day Mongolia: Some preliminary observations from Khanuy Valley. In L. M. Popova, C. W. Hartley, \& A. T. Smith (Eds.), Social orders and social landscapes (pp. 151-167). Cambridge Scholars.

Amzarakov, P. B., Lazaretov, I. P., \& Polyakov, A. V. (2015). Pogrebeniye final'noy stadii epokhi pozdney bronzy v istokakh reki Idzhim (Yermakovskiy rayon Krasnoyarskogo kraya) (Погребение 
финальной стадии эпохи поздней бронзы в истоках реки Иджим [Ермаковский район Красноярского края]: Burial of the final stage of the Late Bronze Age in the headwaters of the Idzhim River [Ermakovsky District, Krasnoyarsk Territory]). Vestnik NGU. Seriya: Istoriya, filologiya (Вестник НГУ. Серия: История, филология: Vestnik NSU. Series: History, Philology), 14(7), 72-83.

Anhuisheng W. K. Y., \& Bengbushi B. (2013). Zhonglijun Bai mu (钟离君柏墓: The tomb of Lord Bai of the Zhongli state). 3 vols. Beijing: Wenwu Chubanshe.

Beckwith, C. I. (2009). Empires of the Silk Road: A history of central Eurasia from the Bronze Age to the present. Princeton University Press.

Beidong, W. F. X. (1974). Liaoning Kazuoxian Beidongcun chutu de Yinzhou qingtongqi (辽宁喀左县 北洞村出土的殷周青铜器: Shang-Zhou period bronzes unearthed at Beidong, Kazuo County). Kaogu (考古: Archaeology), 6, 364-372.

Beijing, D. K. S. Z. Z., \& Shanxisheng K.Y. (2000). Tianma-Qucun (1980-1989) (天马一曲村 [19801989]: The Tianma-Qucun site). 4 vols. Kexue Chubanshe.

Beijingshi, W.G. (1976). Beijing diqu de youyi zhongyao kaogu shouhuo: Changping Baifu Xizhou muguomu de xinqishi (北京地区的又一重要考古收获: 昌平白浮西周木楟墓的新启示: Another important archaeological discovery in Beijing: new ideas from the wooden outer coffin tombs discovered at Baifu, Changping). Kaogu (考古: Archaeology), 4, 246-258.

Beijingshi, W.Y. (1995). Liulihe Xizhou Yanguo mudi: 1973-1977 (琉璃河西周燕国墓地: 1973-1977: The Western Zhou Yan state cemetery at Liulihe: 1973-1977). Wenwu Chubanshe.

Beijingshi, W. Y. (2010). Jundushan mudi: Yuhuangmiao (军都山墓地: 玉皇庙: Yuhuangmiao at the Jundushan cemetery). 4 Vols. Wenwu Chubanshe.

Boroffka, N. (1998). Bronze- und früheisenzeitliche Geweihtrensenknebel aus Rumänien und ihre Beziehungen: Alte Funde aus dem Museum für Geschichte Aiud Teil II. Eurasia Antiqua, 4, 81-135.

Britnell, W. J. (1976). Antler cheekpieces of the British Late Bronze Age. The Antiquaries Journal, $56(1), 24-34$.

Brook, T. (2019). Great state: China and the world. Profile Books.

Cao, D. (2014). The Loess highland in a trading network (1300-1050 BC). PhD dissertation, Princeton University.

Chechushkov, I. V., \& Epimakhov, A. V. (2018). Eurasian Steppe chariots and social complexity during the Bronze Age. Journal of World Prehistory, 31(4), 435-483.

Chechushkov, I. V., Epimakhov, A. V., \& Bersenev, A. G. (2018). Early horse bridle with cheekpieces as a marker of social change: An experimental and statistical study. Journal of Archaeological Science, $97,125-136$.

Chen, C. (Ed.) (2015). Baoji Daijiawan yu Shigushan chutu Shang Zhou qingtongqi (寶雞戴家灣與石 鼓山出土商周青銅器: Shang and Zhou bronzes from Daijiawan and Shigushan at Baoji). Taipei: Chungyang Yenchiuyuan Lishih Yuyen Yenchiuso (中央研究院歷史語言研究所); Shaanxi Kaogu Yanjiuyuan.

Chen, K., Mei, J., \& Sun, B. (2009). Liangdaicun liang Zhou mudi chutu qingtongqi chubu jiance fenxi (梁带村两周墓地出土青铜器初步检测分析: Preliminary scientific analysis on bronze objects unearthed from Zhou cemetery of Liangdaicun). Kaogu yи Wenwu (考古与文物: Archaeology and Cultural Relics), 6, 91-95.

Chen, K., Mei, J., Shao, A., Liu, J. \& Hao, M. (2015). Shaanxi Baoji Shigushan xinchu Xizhou tongjia de chubu kexue fenxi (陕西宝鸡石鼓山新出西周铜甲的初步科学分析: The scientific analysis on the Western Zhou armour from Shigushan, Baoji). Wenwu (文物: Cultural Relics), 4, 68-75.

Cooke, B. (2000). Imperial China: The art of the horse in Chinese history. Exhibition catalog. Kentucky Horse Park.

Chu, S. (1977). Gansu Lingtai baicaopo Xizhoumu (甘肃灵台白草坡西周墓: The Western Zhou tomb at Baicaopo, Lingtai, Gansu). Kaogu xuebao (考古学报: Acta Archaeologica Sinica), 2, 99-130.

Chugunov, K. V., Parzinger, H., \& Nagler, A. (2010). Der skythenzeitliche Fürstenkurgan Aržan 2 in Tuva (The Scythian ruler at Arzhan 2 in Tuva). Mainz: Philipp von Zabern.

Di Cosmo, N. (2002). Ancient China and its enemies: The rise of nomadic power in East Asian history. Cambridge University Press.

Di Cosmo, N. (2020). The 'birth' of the Silk Road between ecological frontiers and military innovation. In J. D. Lerner \& Y. Shi (Eds.), Silk Roads: From local realities to global narratives (pp. 11-20). Oxford/Philadelphia: Oxbow. 
Di Cosmo, N., Hessl, A., Leland, C., Byambasuren, O., Tian, H., Nachin, B., et al. (2018). Environmental stress and steppe nomads: Rethinking the history of the Uyghur Empire (744-840) with paleoclimate data. Journal of Interdisciplinary History, 48(4), 439-463.

Diakakis, N., \& Tyrnenopoulou, P. (2018). Correlation between equine colic and weather changes. Journal of the Hellenic Veterinary Medical Society, 68(3), 455-466.

Dietz, U. L. (2006). 'Cimmerian' bridles: Progress in cavalry technology? In S. L. Olsen, M. A. Littauer, \& I. Rea (Eds.), Horses and humans: The evolution of human-equine relationships (pp. 157-165). Archaeopress.

Drews, R. (2004). Early riders: The beginnings of mounted warfare in Asia and Europe. Routledge.

Durrant, S. W., Li, W.-Y., \& Schaberg, D. (2016). Zuo Tradition/Zuozhuan: Commentary on the 'Spring and Autumn Annals', 3 vols. University of Washington Press.

Esin, Y. N., Magail, J., Gantulga, J.-O., \& Yeruul-Erdene, C. (2021). Chariots in the Bronze Age of Central Mongolia based on the materials from the Khoid Tamir river valley. Archaeological Research in Asia, 27, 100304.

Fages, A., Hanghøj, K., Khan, N., Gaunitz, C., Seguin-Orlando, A., Leonardi, M., et al. (2019). Tracking five millennia of horse management with extensive ancient genome time series. Cell, 177(6), 1419-1435.

Falkenhausen, L. (2006). Chinese society in the age of Confucius (1000-250 BC): The archaeological evidence. Cotsen Institute of Archaeology, University of California.

Fitzhugh, W. W. (2009). The Mongolian deer stone-khirigsuur complex: Dating and organisation of a Late Bronze Age Menagerie. In J. Bemmann, H. Parzinger, E. Pohl, \& D. Tseveendorzh (Eds.), Current archaeological research in Mongolia: Papers from the First International conference on "Archaeological Research in Mongolia" held in Ulaanbaatar, August 19th-23rd, 2007 (pp. 183199). Vor- und Frühgeschichtliche Archäologie, Rheinische Friedrich-Wilhelms-Universität.

Fonseca, L., Gonçalves, R., Ribeiro Filho, J., Girardi, F., Filho, W., Dias, D., \& Bento, L. (2016). Influence of selenium and vitamin E supplementation on energy metabolism in horses used in policing activity. Comparative Clinical Pathology, 25(2), 351-355.

Gansusheng, W. K. Y. (2009). Chongxin Yujiawan Zhoumu (崇信于家湾周墓: The Zhou period tombs at Yujiawan, Chongxin County). Wenwu Chubanshe.

Gaunitz, C., Fages, A., Hanghøj, K., Albrechtsen, A., Khan, N., Schubert, M., et al. (2018). Ancient genomes revisit the ancestry of domestic and Przewalski's horses. Science, 360(6384), 111-114.

Gosden, C., Hommel, P. N., \& Nimura, C. (2019). Making mounds: Monuments in Euasian prehistory. In T. Romankiewicz, M. Fernández-Götz, G. R. Lock, \& O. Buchsenschutz (Eds.), Enclosing space, opening new ground: Iron Age studies from Scotland to mainland Europe (pp. 141-152). Oxbow Books.

Grass, N. (2019). A million horses: Raising government horses in early Ming China. In R. Kowner, G. Bar-Oz, M. Biran, M. Shahar, \& G. Shelach-Lavi (Eds.), Animals and human society in Asia: Historical, cultural and ethical perspectives (pp. 299-328). Springer.

Grieß, B., Dewall, M., \& v., Kröning, K. \& Reuß, S. (2010). Wagenfahrt ins Jenseits: Das Gräberfeld von Zhangjiapo als Kulturzeugnis der späten Bronzezeit in Zentralchina. In M. Wagner \& W. Wang (Eds.), Bridging Eurasia. Archäologie in China 1 (pp. 43-123). Verlag Philipp von Zabern.

Grjaznov, M. P. (1984). Der Grosskurgan von Arzan in Tuva. Beck: Südsibirien.

Grupe, G., Marx, M., Schellerer, P.-M., Bemmann, J., Brosseder, U., Yeruul-Erdene, C., et al. (2019). Bioarchaeology of Bronze and Iron Age skeletal finds from a microregion in Central Mongolia. Anthropologischer Anzeiger, 76(3), 233-243.

Hansen, V. (2012). The Silk Road: A new history. Oxford University Press.

Henansheng, W. K. Y. \& Pingdingshanshi, W. G. (2012). Pingdingshan Yingguo mudi (平顶山应国墓 地: The Ying state cemetery in Pingdingshan). 2 vols. Zhengzhou: Daxiang Chubanshe.

Henansheng W. K. Y., \& Sanmenxiashi, W. G. (1999). Sanmenxia Guoguo mu (三门峡虢国墓 (第一卷): The Guo state cemetery in Sanmenxia). 2 vols. Wenwu Chubanshe.

Honeychurch, W. (2014). Alternative complexities: The archaeology of pastoral nomadic states. Journal of Archaeological Research, 22(4), 277-326.

Honeychurch, W. (2015). Inner Asia and the spatial politics of empire: Archaeology, mobility, and culture contact. Springer.

Horvath, V. (2020). Zakhoroneniya koney v kamere No 31 kurgana Arzhan-1 (novyye dannyye o kul'turnykh svyazyakh v yevraziyskikh stepyakh v VIII - nachale VI. vv. do n. е.) (Захоронения коней в камере №31 кургана Аржан-1 [новые данные о культурных связях в евразийских степях в VIII - начале VI. вв. до н. э.]: Horse burials in chamber no. 31 of the Arzhan-1 mound 
[new data on cultural connections in the Eurasian steppes in the 8th-early 6th centuries BC]). Teoriya $i$ praktika arkheologicheskikh issledovaniy (Теория и практика археологических исследований: Theory and practice of archaeological research), 31(3), 134-153.

Hubeisheng, B., Hubeisheng, W. K. Y., \& Suizhoushi B. (Eds.) (2013). Suizhou Yejiashan: Xizhou zaoqi Zengguo mudi (随州叶家山: 西周早期曾国墓: The Western Zhou Zeng state cemetery at Yejiashan, Suizhou). Wenwu Chubanshe.

Huang, C., Zhao, S., Pang, J., Zhou, Q., Chen, S., Li, P., et al. (2003). Climatic aridity and the relocations of the Zhou culture in the southern Loess Plateau of China. Climatic Change, 61(3), 361-378.

Huang, T. (2013). Liuguang yicai, cuirao zhuwei: Xizhou zhi Chuqiu zaoqi de tixingpai lianzhu chuanshi (流光溢彩, 翠繞珠圍: 西周至春秋早期的梯形牌聯珠夰飾: Gleaming and exuberant: beadstrings with trapezoidal plaque from Western Zhou to the early Spring and Autumn periods). In: C. Kwang-tzuu (Ed.), Jinyu Jiaohui: Shang Zhou kaogu, yishu yu wenhua lunwenji (金玉交輝: 商 周考古、藝術與文化論文集: Radiance between bronze and jade: archaeology, art and culture of the Shang and Zhou dynasties) (pp. 559-600). Chungyang Yenchiuyuan Lishih Yuyen Yenchiuso.

Hwang, M. (2012). Cong kaogu faxian kan xi Zhou muzang de "fenqi" xianxiang yu xi Zhou shidai liqi zhidu de leixing yu jieduan (1) (從考古發現看西周墓葬的「分器」現象與西周時代禮器制度 的類型與階段 [上篇]: The “fenqi” phenomena in Western Zhou tombs observed in archaeological discoveries and types and stages of ritual system during the Western Zhou period). Chungyang Yenchiuyuan Lishih Yuyen Yenchiuso chik'an (中央研究院歷史語言研究所集刊: Bulletin of the Institute of History and Philology Academia Sinica), 83, 607-670.

Ji, L., \& Zhang, J. (1993). Tianjin Jixian Zhangjiayuan yizhi disanci fajue (天津蓟县张家园遗址第三次 发掘: The third excavation of Zhangiiayuan, Ji County). Kaogu (考古: Archaeology), 4, 311-323.

Kelekna, P. (2009). The horse in human history. Cambridge University Press.

Khayutina, M. (2017a). Kinship, marriage and politics in early China (13-8 . BCE) in the light of ritual bronze inscriptions. Habilitation thesis, Ludwig Maximilian University of Munich.

Khayutina, M. (2017b). The tombs of the rulers of Peng and relationships between Zhou and northern non-Zhou lineages (until the early ninth century BC). In E. L. Shaughnessy (Ed.), Imprints of kinship: Studies of recently discovered bronze inscriptions from ancient China (pp. 71-132). CUHK Press.

Kuzmina, E. E. (2008). The prehistory of the Silk Road. Mair, V. H. (trans.). University of Pennsylvania Press.

Littauer, M. A. (1969). Bits and pieces. Antiquity, 43(172), 289-300.

Li, F. (2006). Landscape and power in early China: The crisis and fall of the Western Zhou, 1045-771 $B C$. Cambridge University Press.

Li, S. (2018). The mace-head: A significant evidence of the early cultural interaction between West and East. Social Evolution \& History, 17(2), 258-272.

Li, S., \& Bañuelos, Wu, L. \& Shi, W., G. (2014). The changing selenium nutritional status of Chinese residents. Nutrients, 6(3), 1103-1114.

Li, Y., Zhang, C., Taylor, W. T. T., Chen, L., Flad, R. K., Boivin, N., et al. (2020). Early evidence for mounted horseback riding in northwest China. Proceedings of the National Academy of Sciences, 117(47), 29569.

Librado, P., Khan, N., Fages, A., Kusliy, M. A., Suchan, T., Tonasso-Calvière, L., et al. (2021). The origins and spread of domestic horses from the Western Eurasian steppes. Nature, 598(7882), 634-640.

Librado, P., \& Orlando, L. (2021). Genomics and the evolutionary history of equids. Annual Review of Animal Biosciences, 9(1), 81-101.

Lin, Y. (1986). A reexamination of the relationship between bronzes of the Shang culture and of the Northern Zone. In K.-C. Chang (Ed.), Studies of Shang archaeology: Selected papers from the International Conference on Shang Civilization (pp. 237-273). Yale University Press.

Linduff, K. M., Sun, Y., Cao, W., \& Liu, Y. (2017). Ancient China and its Eurasian neighbors: Artifacts, identity and death in the frontier, 3000-700 BCE. Cambridge University Press.

Liu, G., \& Xu, G. (1975). Ningcheng Nanshan'gen yizhi fajue baogao (宁城南山根遗址发掘报告: The excavation of Nanshan'gen in Ningcheng County). Kaogu xuebao (考古学报: Acta Archaeologica Sinica), 1, 117-140.

Liu, J., Wang, J., Xin, Y., Wang, Z., Hao, M., Wang, X., et al. (2013). Shaanxi Baoji Shigushan Xizhou muzang fajue jianbao (陕西宝鸡石鼓山西周墓葬发掘简报: The excavation of the Western Zhou tombs at Shigushan in Baoji, Shaanxi). Wenwu (文物: Cultural Relics), 2, 4-54. 
Liulihe, K. (1990). Beijing Liulihe 1193 hao damu fajue jianbao (北京琉璃河1193号大墓发掘简报: The excavation of tomb no. 1193 at Liulihe, Beijing). Kaogu (考古: Archaeology), 1, 20-31.

Lu, L. (1987). 1984-85 nian Fengxi Xizhou yizhi, muzang fajue baogao (1984-85年浅西西周遗址、 墓葬发掘报告: The excavation of Western Zhou settlement and burial sites at Fengxi, 1984-85 season). Kaogu (考古 Archaeology), 1, 15-32.

Lu, L., \& Hu, Z. (1988). Baoji Yuguo mudi (宝鸡弓鱼国墓地 Yu state cemeteries in Baoji). 2 vols. Wenwu Chubanshe.

Matyushchenko, V. I., \& Sinitsyna, G. V. (1988). Mogil'nik u derevni Rostovka vblizi Omska (Могильник у деревни Ростовка вблизи Омска: The burial site near the village of Rostovka in the suburbs of Omsk). Tomsk State University.

Marek, K. (2019). Selenium-fascinating microelement, properties and sources in food. Molecules (Basel, Switzerland), 24(7), 1298.

Neimenggu, Z. W. K. Y., \& Ningchengxian, L. Z. B. (2009). Xiaoheishigou: Xiajiadian shangceng wenhua yizhi fajue baogao (小黑石沟: 夏家店上层文化遗址发掘报告: The excavation of the Upper Xiajiadian culture site at Xiaoheishigou). Kexue Chubanshe.

Novozhenov, V. I. (2012). Communication of the earliest wheeled transport of Eurasia. Taus Publishing.

Outram, A. K., Stear, N. A., Bendrey, R., Olsen, S., Kasparov, A. K., Zaibert, V., et al. (2009). The earliest horse harnessing and milking. Science, 323(5919), 1332-1335.

Peterson, C. E., \& Lu, X. (2013). Understanding Hongshan period social dynamics. In A. P. Underhill (Ed.), A companion to Chinese archaeology (pp. 55-80). Wiley-Blackwell.

Piggott, S. (1962). Heads and hoofs. Antiquity, 36(142), 110-118.

Podobed, V. A., Usachuk, A. N. \& Tsimidanov, V. V. (2014). Vznuzdavshiye loshad' (sterzhnevidnyye psalii Yevrazii kontsa II-nachala I tys. do n.e.: tipologicheskiye i khronologicheskiye sopostavleniya) (Взнуздавшие лошадь [стержневидные псалии Евразии конца II — начала I тыс. до н.э.: типологические и хронологические сопоставления]: Those who bridled a horse [rodlike cheek-pieces of Eurasia of the late 2nd-early 1st mill. BC: typological and chronological comparisons]). In V. I. Soenov (Ed.), Drevnosti Sibiri i Tsentral'noy Azii. Sbornik nauchnykh trudov, posvyashchennyy уиbileуи (Древности Сибири и Центральной Азии. Сборник научных трудов, посвященный юбилею: Antiquities of Siberia and Central Asia. Collection of scientific papers dedicated to the anniversary) (pp. 85-118). Gorno-Altaisk State University.

Qi, X. (1979). Beijingshi Yanqingxian Xibozicun jiaocang tongqi (北京市延庆县西拨子村窝藏铜器: A bronze hoard found at Xibozi, Yanqing County). Kaogu (考古: Archaeology), 3, 227-230.

Rawson, J. (1999). Western Zhou archaeology. In M. Loewe \& E. L. Shaughnessy (Eds.), The Cambridge history of ancient China: From the origins of civilization to 221 BC (pp. 352-449). Cambridge: Cambridge University Press.

Rawson, J. (2013). Ordering the exotic: Ritual practices in the Late Western and Early Eastern Zhou. Artibus Asiae, 73(1), 5-76.

Rawson, J., Chugunov, K. V., Grebnev, Y., \& Huan, L. (2020). Chariotry and prone burials: Reassessing late Shang China's relationship with its northern neighbours. Journal of World Prehistory, 33(2), 135-168.

Rayman, M. P. (2000). The importance of selenium to human health. Lancet, 356(9225), 233-241.

Shaanxisheng, K. Y., Weinanshi, W. B. K. Y., \& Hanchengshi, J. G. W. (2010). Liangdaicun Ruiguo mudi: 2007 nian fajue baogao (梁带村苪国墓地: 2007年度发掘报告: The cemetery of Rui state at Liangdai village: An excavation report of 2007). Wenwu Chubanshe.

Shaanxisheng, K. Y., Yan'anshi, W. Y., \& Huanglingxian, L. W. (2018). Zhaitouhe: Shaanxi Huangling Zhanguo Rongren mudi kaogu fajue baogao (寨头河: 陕西黄陵战国戎人墓地考古发掘报告: Zhaitouhe: the excavation of the Warring-States-period Rong-barbarian cemetery at Huangling, Shaanxi). Shanghai Guji Chubanshe.

Shanxisheng, K. Y., \& Taiyuanshi, W. G. W. (1996). Taiyuan Jinguo Zhaoqing mu (太原晋国赵卿墓: Tomb of Jin state minister Zhao near Taiyuan). Wenwu Chubanshe.

Shanghai, B. (2014). Zhouye luming: Baoji Shigushan Xizhou guizu mu chutu qingtongqi (周野鹿鸣: 宝 鸡石鼓山西周贵族墓出土青铜器: Noble life of the Zhou: bronzes unearthed from the Cemetery of the Western Zhou Aristocrats at Shigushan of Baoji). Shanghai Shuhua Chubanshe.

Shao, H., \& Shi, C., (2018). Zhongguo beifang diqu xian Qin shiqi mabiao yanjiu 1 (中国北方地区先秦 时期马镳研究 (一): Research on bridle bits during the pre-Qin period in Chinese Northern Zone 1). Caoyuan wenwu (草原文物: Steppe Cultural Relics), 2, 35-53. 
Shao, H., \& Shi, C. (2019). Zhongguo beifang diqu xian Qin shiqi mabiao yanjiu 2 (中国北方地区先秦 时期马镳研究 (二): Research on bridle bits during the pre-Qin period in Chinese Northern Zone 2). Caоyuan wenwu (草原文物: Steppe Cultural Relics), 1, 54-71.

Shaughnessy, E. L. (1999). Western Zhou history. In M. Loewe \& E. L. Shaughnessy (Eds.), The Cambridge history of ancient China: From the origins of civilization to 221 BC (pp. 293-351). Cambridge: Cambridge University Press.

Shulga, P. I. (2015). Mogil'nik Yuykhuanmyao v Severnom Kitaye (VII-VI veka do nashey ery) (Могильник Юйхуанмяо в Северном Китае [VII-VI века до нашей эры]: The cетеtеry of Yuhuangmiao in northern China [the 7th-6th centuries BC]). Institute of Archaeology and Ethnography SB RAS.

Shulga, P. I. (2020). Mysterious transformations of the Scythian cultures in the 6th and 3rd centuries BC. In S. Pankova \& S. J. Simpson (Eds.), Masters of the steppe: The impact of the Scythians and later nomad societies of Eurasia. Proceedings of a conference held at the British Museum, 27-29 October 2017 (pp. 522-524). Archaeopress.

Skaff, J. K. (2012). Sui-Tang China and its Turko-Mongol neighbors: Culture, power, and connections, 580-800. Oxford University Press.

Stepanova, E. V. \& Chugunov, K. V. (2019). Konskoye snaryazheniye epokhi pozdney bronzy v Drevnem Kitaye: Revolyutsiya i evolyutsiya (Конское снаряжение эпохи поздней бронзы в Древнем Китае: Революция и эволюция: Equestrian equipment of the Late Bronze Age in Ancient China: Revolution and evolution). In A. V. Polyakov \& E. S. Tkach (Eds.), Drevnosti Vostochnoy Yevropy, Tsentral'noy Azii i Yuzhnoy Sibiri v kontekste svyazey $i$ vzaimodeystviy v yevraziyskom kul'turnom prostranstve (novyye dannyye $i$ kontseptsii)(Древности Восточной Европы, Центральной Азии и Южной Сибири в контексте связей и взаимодействий в евразийском культурном пространстве [новые данные и концепции]: Antiquities of East Europe, South Asia and south Siberia in the context of connections and interactions within the Eurasian cultural space [new data and concepts]) (pp. 95-97). IIMK - State Hermitage Museum.

Sun, B., Cheng, R., Chen, J., Li, G., Wang, Z., Tong, X., et al. (2007). Shaanxi Hancheng Liangdaicun yizhi M27 fajue jianbao (陕西韩城梁带村遗址M27发掘简报: The excavation of tomb M27 at Liangdaicun, Hancheng County). Kaogu yu wenwu (考古与文物: Archaeology and Cultural Relics), 6, 3-22.

Sun, G., Meharg, A. A., Li, G., Chen, Z., Yang, L., Chen, S., et al. (2016). Distribution of soil selenium in China is potentially controlled by deposition and volatilization? Scientific Reports, 6, 20953.

Sun, Y. (2018). A divergent life history of bronze willow-leaf-shaped swords of Western Zhou China from the eleventh to the tenth century BCE: Shaping the life history of objects. In F. Allard, Y. Sun, \& K. M. Linduff (Eds.), Memory and agency in ancient China: Shaping the life history of objects (pp. 120-151). Cambridge University Press.

Sun, Y. (2021). Many worlds under one heaven: Material culture, identity, and power in the northern frontiers of the Western Zhou, 1045-771 BCE. Columbia University Press.

Tackett, N. (2017). The origins of the Chinese nation: Song China and the forging of an East Asian world order. Cambridge University Press.

Takahama, S. (2011). Seisyū zidai no kokkakusei no hyō no issyu nituite (西周時代の骨角製の鏕の一 種について: On one type of bone or horn cheek-pieces of the Western Zhou period). Kanazawadaigaku kōkogaku kiyo (金沢大学考古学紀要: Bulletin of Archaeology, the University of Kanazawa), 32, 1-12.

Takahama, S. (2020). Two technical traditions of casting horse bits in China and their relationships with the steppe area. Asian Archaeology, 3(1), 47-57.

Taylor, T. F., Havlicek, C. M., \& Beckwith, C. I. (2020). The Scythian empire: Reassessing steppe power from western and eastern perspectives. In S. Pankova \& S. J. Simpson (Eds.), Masters of the steppe: The impact of the Scythians and later nomad societies of Eurasia. Proceedings of a conference held at the British Museum, 27-29 October 2017 (pp. 616-626). Archaeopress.

Taylor, W. T. T., \& Barrón-Ortiz, C. I. (2021). Rethinking the evidence for early horse domestication at Botai. Scientific Reports, 11(1), 7440.

Taylor, W. T. T., Bayarsaikhan, J., \& Tuvshinjargal, T. (2015). Equine cranial morphology and the identification of riding and chariotry in late Bronze Age Mongolia. Antiquity, 89(346), 854-871.

Taylor, W. T. T., Cao, J., Fan, W., Ma, X., Hou, Y., Wang, J., et al. (2021). Understanding early horse transport in eastern Eurasia through analysis of equine dentition. Antiquity, 95(384), 1478-1495. https://doi.org/10.15184/aqy.2021.146 
Taylor, W. T. T., Jargalan, B., Lowry, K. B., Clark, J., Tuvshinjargal, T., \& Bayarsaikhan, J. (2017). A Bayesian chronology for early domestic horse use in the Eastern Steppe. Journal of Archaeological Science, 81, 49-58.

Taylor, W. T. T. \& Tuvshinjargal, T. (2018). Horseback riding, asymmetry, and changes to the equine skull: Evidence for mounted riding in Mongolia's late Bronze Age. In L. Bartosiewicz \& E. Gál (Eds.), Care or neglect? Evidence of animal disease in archaeology: Proceedings of the 6th meeting of the Animal Palaeopathology Working Group of the International Council for Archaeozoology (ICAZ), Budapest, Hungary, 2016 (pp. 134-154). Oxbow Books.

Taylor, W. T. T., Tuvshinjargal, T., \& Bayarsaikhan, J. (2016). Reconstructing equine bridles in the Mongolian Bronze Age. Journal of Ethnobiology, 36(3), 554-570.

Taylor, W. T. T., Wilkin, S., Wright, J., Dee, M., Erdene, M., Clark, J., et al. (2019). Radiocarbon dating and cultural dynamics across Mongolia's early pastoral transition. PLOS ONE, 14(11), e0224241.

Tong, E. (1987). Shilun woguo cong dongbei zhi xi'nan de biandi banyuexing wenhua chuanbodai (试论 我国从东北至西南的边地半月形文化传播带: On the crescent-shaped cultural-contact belt from Northeast to Southwest China). In W. C. Bianjibu (Ed.), Wenwu yu kaogu lunji (文物与考古论集: Papers on cultural relics and archaeology) (pp. 17-43). Wenwu Chubanshe.

Twitchett, D. \& Loewe, M. (1986). The Cambridge history of China. Vol. 1: the Ch'in and Han Empires, $221 B C-A D$ 220. Cambridge University Press.

Usachuk, A. N. (2010). Rekonstruktsii krepleniya drevneyshikh psaliyev v sisteme remney ogolov'ya loshadi: Protivorechiya i perspektivy (Реконструкции крепления древнейших псалиев в системе ремней оголовья лошади: Противоречия и перспективы: Reconstruction of ancient cheek-piece attachment in the system of horse head bands: Contradictions and prospects). In P. F. Kuznetsov (Ed.), Koni, kolesnitsy i kolesnichiye stepey Yevrazii (Кони, колесниць и колесничие степей Евразии: Horses, chariots, and chariot drivers of the Eurasian Steppes) (pp. 257-291). Rifey.

van Geel, B., Bokovenko, N. A., Burova, N. D., Chugunov, K. V., Dergachev, V. A., Dirksen, V. G., et al. (2004). The sun, climate change and the expansion of the Scythian culture after 850 BC. In E. M. Scott, A. Y. Alekseev, \& G. I. Zaitseva (Eds.), Impact of the environment on human migration in Eurasia (pp. 151-158). Kluwer Academic.

Volkov, V. V. (2002). Olennyуe kamni Mongolii (Оленные камни Монголии: Deer stones from Mongolia). Nauchnyy Mir.

Wagner, M., Wu, X., Tarasov, P., Aisha, A., Ramsey, C. B., Schultz, M., et al. (2011). Radiocarbon-dated archaeological record of early first millennium B.C. mounted pastoralists in the Kunlun Mountains, China. Proceedings of the National Academy of Sciences USA, 108(38), 15733.

Waley, A. (1954). The book of songs. George Allen \& Unwin.

Wang, Z., Ding, Y., Liu, J., Xin, Y., Hao, M., \& Wang, X. (2016). Shaanxi Baoji Shigushan Shang Zhou mudi M4 fajue jianbao (陕西宝鸡石鼓山商周墓地M4发掘简报: The excavation of tomb M4 at Shigushan, Baoji). Wenwu (文物: Cultural Relics), (1), 4-52.

Wu, H. (2002). Shang zhi Chunqiu shiqi Zhongyuan diqu qingtong chemaqi xingshi yanjiu (商至春秋时 期中原地区青铜车马器形式研究: A typological study of the bronze chariot fittings in the Central Plains from the Shang dynasty to the Spring and Autumn period). In Beijing Daxue Zhongguo Kaoguxue Yanjiu Zhongxin (北京大学中国考古学研究中心) \& Beijing Daxue Gudai Wenming Yanjiu Zhongxin (北京大学古代文明研究中心) (Eds.), Gudai wenming 1 (古代文明 [第1卷]: Ancient Civilisation 1) (pp. 180-277). Wenwu Chubanshe.

Wu, H. (2013). Chariots in early China: Origins, cultural interaction and identity. Archaeopress.

Xiangfanshi, K., Hubeisheng, W. K. Y., \& Hubei, X. G. G. K. (2005). Zaoyang Guojiamiao Zengguo mudi (冭阳郭家庙曾国墓地: The excavation of the Guojiamiao cemetery in Zaozhuang). Kexue Chubanshe.

Xie, Y., Wang, J., Yang, J., Li, Y., \& Zhao, J. (2018a). Shanxi Yicheng Dahekou Xizhou mudi 2002 hao mu fajue (山西翼城大河口西周墓地2002号墓发掘: The excavation of the tomb M002 at the Dahekou cemetery of the Western Zhou dynasty in Yicheng, Shanxi). Kaogu xuebao (考古学报: Acta Archaeologica Sinica), 2, 223-286.

Xie, Y., Wang, J., Yang, J., \& Li, Y. (2018b). Shanxi Yicheng Dahekou Xizhou mudi 1017 hao mu fajue (山西翼城大河口西周墓地1017号墓发掘: The excavation of the tomb M1017 at the Dahekou cemetery of the Western Zhou dynasty in Yicheng, Shanxi). Kaogu xuebao (考古学报: Acta Archaeologica Sinica), 1, 89-140.

Xie, Y., Zhuo, X., Fan, W., Wang, J., Yang, J., \& Li, Y. (2019). Shanxi Jiangxian Hengshui Xizhou mudi M2158 fajue jianbao (山西绛县横水西周墓地M2158发掘简报: The excavation of tomb M2158 at the Hengshui Western Zhou cemetery in Jiang County). Kaogu (考古: Archaeology), 1, 15-59. 
Xie, Y., Wang, J., Yang, J., Li, Y., \& Zhang, W. (2020a). Shanxi Yicheng Dahekou Xizhou mudi yihaomu fajue (山西翼城大河口西周墓地一号墓发掘: The excavation of tomb M1 at the Western Zhou Dahekou cemetery in Yicheng County). Kaogu xuebao (考古学报: Acta Archaeologica Sinica), 2, 177-290.

Xie, Y., Wang, J., Yang, J., Li, Y., \& Zhang, W. (2020b). Shanxi Yicheng Dahekou Xizhou mudi M6096 fajue jianbao (山西翼城大河口西周墓地M6096发掘简报: Excavation of tomb M6096 at Dahekou, Yicheng County). Wenwu (文物: Cultural Relics), 1, 4-25.

Xu, C., Li, J., Wei, Z., Han, X. \& Yan, S. (1993). Ningxia Guyuan Yanglang qingtong wenhua mudi (宁 夏固原杨郎青铜文化墓地: Bronze culture cemetery at Yanglang, Guyuan, Ningxia). Kaogu xuebao (考古学报: Acta Archaeologica Sinica), 1, 13-56.

Yang, J., Shao, H., \& Pan, L. (2020a). The metal road of the eastern Eurasian Steppe: The formation of the Xiongnu confederation and the Silk Road. Springer.

Yang, S. (1981). Shanxi Liulinxian Gaohong faxian Shangdai tongqi (山西柳林县高红发现商代铜器: Shang period bronzes found at Gaohong, Liulin County). Kaogu (考古: Archaeology), 3, 211-212.

Yang, X., \& Liu, Y. (1998). Henan Anyangshi Meiyuanzhuang dongnan de Yindai chemakeng (河南安 阳市梅园庄东南的殷代车马坑: Yin chariot pits at southeast Meiyuanzhuang in Anyang). Kaogu (考古: Archaeology), 10, 48-65.

Yue, Z. (2006). 2000-2001 nian Anyang Xiaomintun dongnandi Yindai zhutong yizhi fajue baogao 2000-2001 (2000-2001年安阳孝民屯东南地殷代铸铜遗址发掘报告: Excavation of the bronze foundry site in the southeast of Xiaomintun, Anyang, 2000-2001). Kaogu xuebao (考古学报: Acta Archaeologica Sinica), 2, 351-381.

Zhang, C. (2014). Lun banhuanxing yue jiqi wenhua Beijing (论半环形铖及其文化背景: On the crescent-shaped axe and its cultural background). In S. K. Yanjiuyuan \& S. Bowuguan (Eds.), Liang Zhou fengguo lunheng (两周封国论衡: 陕西韩城出土芮国文物暨周代封国考古学研究国际 学术研讨会论文: The International Symposium on Rui State Treasures from Hancheng, Shaanxi Province) (pp. 196-206). Shanghai Guji Chubanshe.

Zhang, C. (2019). Shang Zhou zhiji de fengniaowen you: cong Xiaomintun dao Shigushan (商周之际的 凤鸟纹备: 从孝民屯到石鼓: On bronze you vessels with phoenix-bird motifs during the transition of the Shang and Zhou period: From Xiaomintun to Shigushan). Kaogu yu wenwu (考古与文物: Archaeology and Cultural Relics), 4, 72-79.

Zhang, C., Pollard, A. M., Rawson, J., Huan, L., Liu, R., \& Tang, X. (2019). China's major Late Neolithic centres and the rise of Erlitou. Antiquity, 93(369), 588-603.

Zhang, W., \& Zhai, L. (Eds.) (2016). Houqianyi yizhi kaogu fajue baogao ji Jidong diqu kaoguxue wenhua yanjiu (后迁义遗址考古发掘报告及冀东地区考古学文化研究: The excavation of Houqianyi and the study on regional archaeological cultures in east Hebei). Wenwu Chubanshe.

Zhang, X., Wang, X., Wu, X., Jin, Z., Zhang, H., \& Huang, F. (2018). Investigating human migration and horse-trading in Yelang through strontium isotope analysis of skeletons from Zhougshui sites, south-west China (1300 bc-ad 25). Archaeometry, 60(1), 157-170.

Zhao, C. (Ed.) (2006). Chengyang qingtongqi (城洋青铜器: Bronze artefacts from the Chenggu and the Yang Counties). Kexue Chubanshe.

Zhongguo, S. K. K. Y. (1999). Zhangjiapo Xizhou mudi (张家坡西周墓地: Western Zhou cemetery at Zhangjiapo). Zhongguo Dabaike Quanshu Chubanshe.

Zhongguo, S. K. K. Y. (2007). Anyang Yinxu Huayuanzhuang dongdi Shangdai muzang (安阳殷墟花 园庄东地商代墓葬: Report on the excavations of Huayuanzhuang Locus East in Anyang). Kexue Chubanshe.

Zhongguo, S. K. K. Y. (2014). Anyang Dasikong: 2004 nian fajue baogao (安阳大司空: 2004年发掘报 告: Dasikong in Anyang: report of the excavation in 2004). 2 vols. Beijing: Wenwu Chubanshe ( 文物出版社).

Zhu, L., Liu, Y., Li, C., Liu, S., Fang, H., Xie, Y., et al. (2019). Shanxi Yicheng Dahekou M5010, M6043 shiyan kaogu jianbao (山西翼城大河口M5010、M6043实验室考古简报: Laboratory excavation report of tombs M5010 and M6043 of Dahekou, Yicheng, Shanxi Province). Jianghan kaogu (江 汉考古: Jianghan Archaeology), 2, 3-16.

Publisher's Note Springer Nature remains neutral with regard to jurisdictional claims in published maps and institutional affiliations. 